Document downloaded from:

http://hdl.handle.net/10251/104773

This paper must be cited as:

Gargallo Bellés, S.; Martín Monerris, M.; Oliver Rajadel, N.; Hernández Crespo, C. (2017). Biokinetic model for nitrogen removal in free water surface constructed wetlands. The Science of The Total Environment. 587:145-156. doi:10.1016/j.scitotenv.2017.02.089

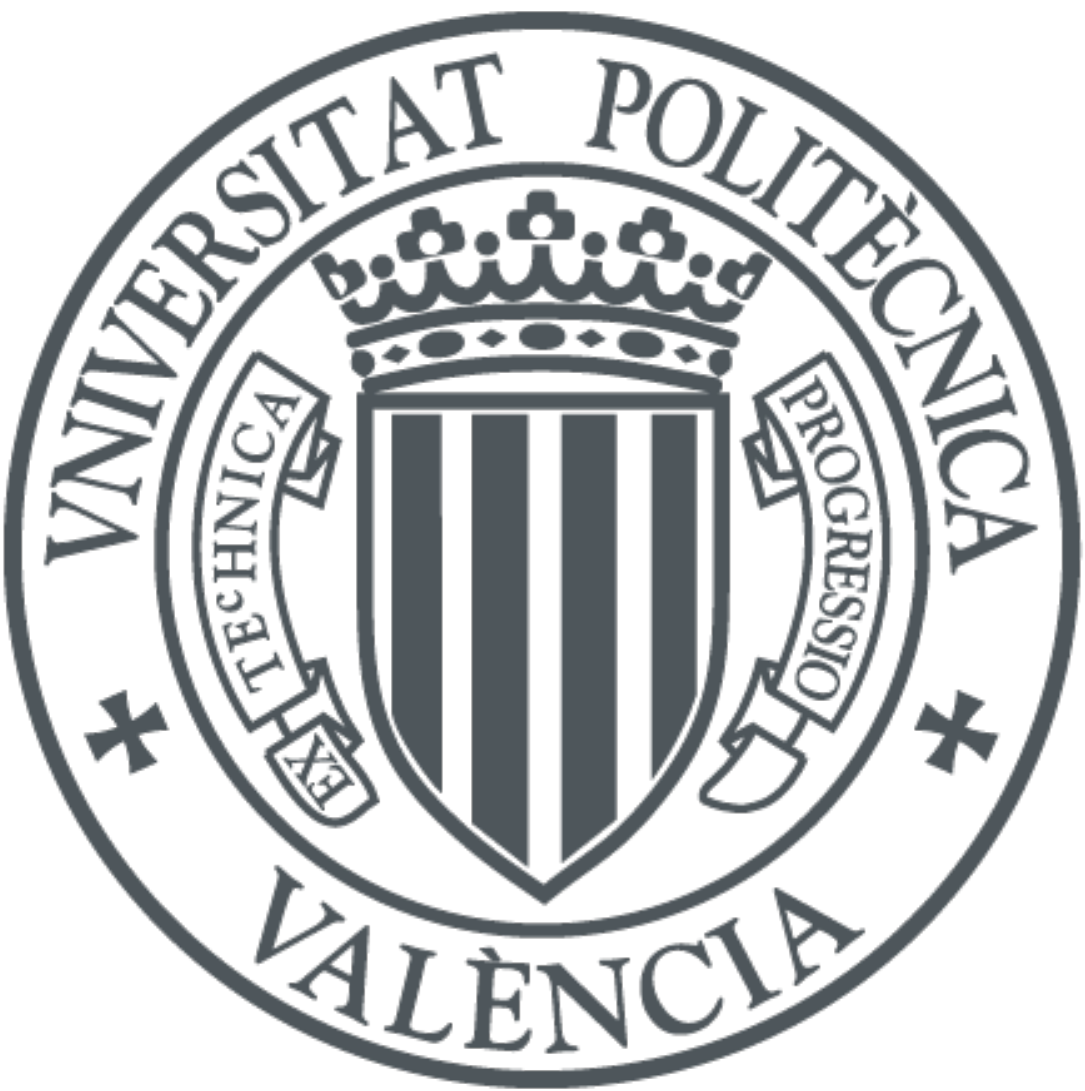

The final publication is available at

https://doi.org/10.1016/j.scitotenv.2017.02.089

Copyright Elsevier

Additional Information 


\title{
Biokinetic model for nitrogen removal in free water surface constructed wetlands
}

\author{
$\underline{\text { S. Gargallo }}{ }^{1 *}$, M. Martín ${ }^{1}$, N. Oliver ${ }^{1}$, C. Hernández-Crespo ${ }^{1}$ \\ ${ }^{1}$ Research Institute of Water and Environmental Engineering \\ Universitat Politècnica de València, Cno. de Vera s/n, Valencia, Spain \\ sagarbel@upv.es
}

7

Keywords: mathematical modelling; ASM; eutrophic water; nitrification; denitrification; plant uptake.

\section{Abstract}

In this article, a mechanistic biokinetic model for nitrogen removal in free water surface constructed wetlands treating eutrophic water was developed, including organic matter performance due to its importance in nitrogen removal by denitrification. Ten components and fourteen processes were introduced in order to simulate the forms of nitrogen and organic matter, the mechanisms of autotrophic and heterotrophic microorganisms in both aerobic and anoxic conditions, as well as macrophytes nitrogen uptake and release. Dissolved oxygen was introduced as an input variable with a time step of 0.5 days for mimicking eutrophic environments: aerobic conditions were assigned during daylight hours and anoxic conditions during the night. The sensitivity analysis showed that the most influential parameters were those related to the growth of heterotrophic and autotrophic microorganisms. The model was properly calibrated and validated in two full scale systems working in real conditions for treating eutrophic water from Lake L'Albufera (València). In the studied systems, ammonium was mainly removed by the growth of autotrophic microorganisms (nitrification) whereas nitrate was removed by the anoxic growth of heterotrophic microorganisms (denitrification). Macrophyte uptake removed between $9-19 \%$ of the ammonium entering to the systems, although degradation of dead standing macrophytes returned a significant part to water column. 


\section{Introduction}

During last decades, multiple efforts have been done in order to preserve natural water bodies from eutrophication. Reducing nutrient loads (mainly, nitrogen and phosphorus) by treating urban wastewater was an important step, but in some cases it was demonstrated to be insufficient for recovering water quality in eutrophicated systems (Martín et al., 2013). For example, in Sweden, where one of the major problems for surface water is eutrophication caused by the diffuse pollution from agricultural sources, 1574 constructed wetlands (CWs) were built between 1996 and 2006 with the aim of reducing agricultural runoff and restoring the Baltic Sea good ecological status (Arheimer and Pers, 2016). Furthermore, some experiences carried out worldwide have demonstrated the usefulness of CWs, both free water surface (FWSCWs) and subsurface flow (SSFCWs) configurations, for treating eutrophic water in order to remove nutrients and phytoplankton biomass (He et al., 2007; Li et al., 2008; Martín et al., 2013; Tang et al., 2009).

CWs efficiency removal depends on a large amount of factors (e.g. inlet concentrations, loading rates, hydraulic configuration, vegetation cover, temperature and $\mathrm{pH}$ ) whose influence can be different for each process. Given the complex task of taking into account the numerous interdependencies, modelling has been demonstrated to be a useful tool for simulating the performance of these systems and many typologies of models have been recently developed. Among them all, mechanistic or process-based models are considered to be the most useful for understanding systems performance (Langergraber, 2008). The vast majority of process-based models have been developed for simulating SSFCWs treating wastewater, being CWM1 (Langergraber et al., 2009), CW2D (Langergraber and Šimůnek, 2005) and BIO-PORE (Samsó and Garcia, 2013) some of the most robust and widely accepted. However, this kind of models are less abundant for simulating FWSCWs and some of the available ones, such as Galanopoulos and Lyberatos (2016), include a limited number of components and interactions. Specifically, seven components and five processes are used in this model for simulating eutrophic water treatment in FWSCWs including nitrogen and organic matter forms, whereas phosphorus influence and interactions between water column and sediment layer were not considered.

One of the most complete models for FWSCWs was developed by Gargallo et al. (2016), where total suspended solids, phytoplankton and phosphorus in eutrophic water were simulated taking into account the effects of avifauna and wind in resuspension processes, as well as vegetation cover (VC) in resuspension and sedimentation mechanisms. In this model, Gargallo et al. considered both organic and total inorganic phosphorus (OP and TIP, 
respectively, mg $\mathrm{P} \mathrm{L}^{-1}$ ) and the last one was divided into soluble (DIP, dissolved inorganic phosphorus) and particulate (PIP, particulate inorganic phosphorus) fractions. Furthermore, phosphorus accumulated inside the phytoplankton cells

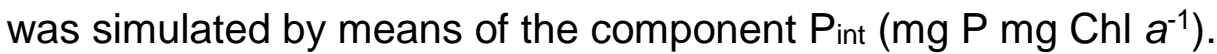

However, nitrogen forms and nutrient uptake by plants were not included in this model.

The aim of this paper is (1) to develop a process-based model for nitrogen performance in free water surface constructed wetlands treating eutrophic water, (2) to calibrate and validate it in two full-scale systems working in real conditions and (3) to look into the main processes in relation to nitrogen removal, focusing mainly in nitrate and ammonium.

\section{Methods}

\subsection{Site description and experimental data}

Experimental data for calibrating and validating the model was collected in a set of two FWSCWs located in the natural reserve area known as Tancat de la Pipa, in València (Spain). Calibration was carried out in the unit named as FG1 $\left(13509 \mathrm{~m}^{2}\right)$ and validation in FG2 $\left(18240 \mathrm{~m}^{2}\right)$. These FWSCWs, which were planted with cattails (Thypa spp.), operated in series in order to treat hypertrophic water from lake L'Albufera.

These systems were monitored from April 2009 to April 2012. During these three years they worked continuously, except in three periods that water input was stopped due to maintenance tasks. More details about CWs configuration and functioning can be found in Martín et al. (2013).

Three points were studied for water quality: P0 at the inlet to FG1 and P1 and $P 2$ at the outlet of FG1 and FG2, respectively. They were monitored every two weeks from April 2009 to October 2011, and monthly from November 2011 to April $2012(n=64)$. Water samples were collected in $2 \mathrm{~L}$ bottles, transported and preserved at $4^{\circ} \mathrm{C}$ until they were analysed in laboratory, no later than $24 \mathrm{~h}$. Ammonium, nitrate, nitrite, total nitrogen (TN), soluble and total chemical oxygen demand (CODs and CODT, respectively) were measured using the Spectroquant ${ }^{\circledR}$ Analysis System by Merck, while dissolved oxygen (DO), pH and temperature were measured in situ using portable field measurement equipment (WTW-Multi 340i). Phosphates, total phosphorus, phytoplankton and total suspended solids, as well as inflow, outflow, meteorological data and VC estimations obtained in Gargallo et al. (2016) and Martín et al. (2013) were used as input data for calibrating and validating the model. 
In order to establish the fractioning of the organic matter measurements into the organic components of the model ( $\mathrm{Ss}, \mathrm{S}_{\mathrm{i}}, \mathrm{X}_{\mathrm{s}}$ and $\mathrm{X}_{\mathrm{i}}$, see Table 1 in next section) one test was carried out in point P0 in February 2010. Particulate and soluble $\mathrm{COD}$ and $\mathrm{BOD}_{5}$ were measured in $\mathrm{PO}\left(\mathrm{COD}_{\mathrm{P}}=18.2, \mathrm{COD}_{\mathrm{s}}=19.8\right.$, particulate $B_{5}=16.0$, soluble $B_{5} D_{5}=3.9 \mathrm{mg} \mathrm{O}_{2} \mathrm{~L}^{-1}$, respectively). Assuming that soluble $\mathrm{BOD}_{5}$ corresponds to $\mathrm{S}_{\mathrm{s}}$ and total $\mathrm{BOD}_{5}$ to the sum of $\mathrm{S}_{\mathrm{s}}$ and $\mathrm{X}_{\mathrm{s}}$, it was obtained that $X_{s}$ and $X_{i}$ correspond to $88 \%$ and $12 \%$ of CODp, respectively, whereas $S_{s}$ and $S_{i}$ to $20 \%$ and $80 \%$ of CODs. These percentages were applied to CODT and CODs measured in the FWSCWs during the studied period.

Once per season, from December 2011 to September 2012, DO and pH were measured every 15 minutes for 24 hours in points P0, P1 and P2. In these point, alkalinity was measured every three weeks from July to December 2015 $(n=8)$ using the methodology by APHA (1991).

\subsection{Model development}

121

122

123

124

125

126

127

128

129

130

131

The Activated Sludge Model series structure (Henze et al., 2000) was used for representing the processes involved in nitrogen removal. Matrix notation was used to represent the effect of each process on each component by means of the specific stoichiometric coefficients and processes kinetic rates. Components included in the model are listed in Table 1 . The capital letter $S$ was used for denoting soluble components and $X$ for particulate ones. Following CWM1 (Langergraber et al., 2009), $\mathrm{S}_{\mathrm{NO} 3}$ was assumed to include the sum of nitrite and nitrate concentrations and for stoichiometric calculations it was considered to be nitrate. Given the relation between nitrogen and organic matter performance, especially in the denitrification process, the later one was included in the model.

Table 1. Description of the components included in the model.

\begin{tabular}{clll}
\hline Components & \multicolumn{1}{c}{ Description } & \multicolumn{1}{c}{ Units } \\
\hline 1. $\mathrm{S}_{\mathrm{NH} 4}$ & Ammonium concentration. & $\mathrm{mg} \mathrm{N} \mathrm{L}^{-1}$ \\
2. $\mathrm{S}_{\mathrm{NO3}}$ & Nitrate concentration. & $\mathrm{mg} \mathrm{N} \mathrm{L}^{-1}$ \\
3. $\mathrm{S}_{\mathrm{s}}$ & Reactive soluble organic matter concentration. & $\mathrm{mg} \mathrm{COD} \mathrm{L}^{-1}$ \\
4. $\mathrm{S}_{\mathrm{i}}$ & Inert soluble organic matter concentration. & $\mathrm{mg} \mathrm{COD} \mathrm{L}$ \\
5. $\mathrm{X}_{\mathrm{s}}$ & Reactive particulate organic matter concentration. & $\mathrm{mg} \mathrm{COD} \mathrm{L}$ \\
$6 . \mathrm{X}_{\mathrm{i}}$ & Inert particulate organic matter concentration. & $\mathrm{mg} \mathrm{COD} \mathrm{L}^{-1}$ \\
7. $\mathrm{X}_{\mathrm{H}}$ & Heterotrophic microorganisms concentration. & $\mathrm{mg} \mathrm{COD} \mathrm{L}^{-1}$ \\
8. $\mathrm{X}_{\mathrm{A}}$ & Autotrophic microorganisms concentration. & $\mathrm{mg} \mathrm{COD} \mathrm{L}^{-1}$ \\
9. $\mathrm{X}_{\mathrm{ml}}$ & Living macrophyte biomass. & $\mathrm{g} \mathrm{COD} \mathrm{m}^{-2}$ \\
10. $\mathrm{X}_{\mathrm{md}}$ & Dead standing macrophyte biomass. & $\mathrm{g} \mathrm{COD} \mathrm{m}^{-2}$ \\
\hline
\end{tabular}

Organic nitrogen (ON), TN, CODs and CODT were obtained by adding the nitrogen or the organic matter content of the corresponding components (Eq. 1 to Eq. 4), where $i_{N \times s}$, $i_{N X i}$, i $i_{N S s}$ and $i_{N S i}\left(m g ~ N ~ m g ~ C O D^{-1}\right)$ are nitrogen content in

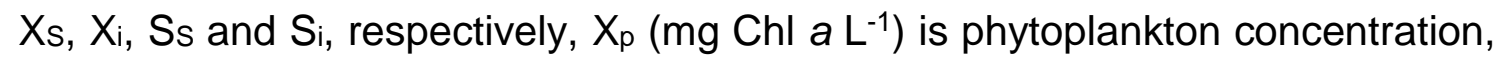


ínxp (mg N mg Chl $\mathrm{a}^{-1}$ ) is nitrogen content in phytoplankton $\left(\mathrm{X}_{\mathrm{P}}\right)$ and icodxp $(\mathrm{mg}$ $138 \mathrm{COD} \mathrm{mg} \mathrm{Chl} \mathrm{a}^{-1}$ ) refers to organic matter content in phytoplankton.

$$
\begin{array}{cc}
\mathrm{ON}=\mathrm{i}_{\mathrm{NXs}} \cdot \mathrm{X}_{\mathrm{S}}+\mathrm{i}_{\mathrm{NXi}} \cdot \mathrm{X}_{\mathrm{i}}+\mathrm{i}_{\mathrm{NSs}} \cdot \mathrm{S}_{\mathrm{s}}+\mathrm{i}_{\mathrm{NSi}} \cdot \mathrm{S}_{\mathrm{i}} & \text { Eq. } 1 \\
\mathrm{TN}=\mathrm{S}_{\mathrm{NH} 4}+\mathrm{S}_{\mathrm{NO} 3}+\mathrm{ON}+\mathrm{i}_{\mathrm{NXp}} \cdot \mathrm{X}_{\mathrm{P}} & \text { Eq. } 2 \\
\mathrm{COD}_{\mathrm{S}}=\mathrm{S}_{\mathrm{s}}+\mathrm{S}_{\mathrm{i}}+4.57 \cdot \mathrm{S}_{\mathrm{NO} 3} & \text { Eq. } 3 \\
\mathrm{COD}_{\mathrm{T}}=\mathrm{COD}_{\mathrm{s}}+\mathrm{X}_{\mathrm{S}}+\mathrm{X}_{\mathrm{i}}+\mathrm{X}_{\mathrm{p}} \cdot \mathrm{i}_{\mathrm{CODXp}} & \text { Eq. } 4
\end{array}
$$

140 The model proposed simulates the hydrolysis of the reactive particulate organic 141 matter $\left(X_{s}\right)$ by means of heterotrophic microorganisms in both aerobic and 142 anoxic conditions. Hydrolysis produces soluble reactive and inert organic matter 143 ( $\mathrm{S}_{\mathrm{s}}$ and $\left.\mathrm{S}_{\mathrm{i}}\right)$ as well as ammonium, which is taken as nutrient supply by living 144 macrophyte biomass $\left(X_{\mathrm{ml}}\right)$, phytoplankton $\left(X_{\mathrm{P}}\right)$, heterotrophic microorganisms $145\left(X_{H}\right)$ and autotrophic microorganisms $\left(X_{A}\right)$ in their growth processes. The growth 146 of $X_{A}$ generates nitrate that can also be used as nutrient by $X_{m l}$ and $X_{P}$, 147 although ammonium is preferred. Nitrate is used as electron acceptor for $X_{H}$ 148 growth in anoxic conditions, reducing it to $\mathrm{N}_{2}$ gas, which is not included in the 149 model. Lysis of $\mathrm{X}_{H}$ and $\mathrm{X}_{\mathrm{A}}$, decay and respiration of $\mathrm{X}_{\mathrm{P}}$ and degradation of dead 150 standing macrophyte biomass $\left(X_{\mathrm{md}}\right)$ recycle ammonium and organic matter to 151 the water column. On the other hand, interactions between water column and 152 sediment layer are included through sedimentation processes of $\mathrm{X}_{\mathrm{s}}$ and $\mathrm{X}_{\mathrm{i}}$, 153 resuspension of nitrogen and organic matter content in sediments and diffusion 154 of ammonium and nitrate. Sedimentation and resuspension processes are 155 modelled following Gargallo et al. (2016).

156 The preferential consumption of ammonium instead of nitrate by $X_{P}$ was 157 modelled using the preferential factor $\mathrm{FP}_{\mathrm{NH} 4}$ by Thomann and Fitzpatrick (1982) 158 (Eq. 5), where $\mathrm{kmN}$ is the saturation coefficient for ammonium. In macrophyte 159 uptake, it was introduced as an inhibition function for ammonium in the nitrate 160 uptake by plant (Rousseau, 2005). Uptake processes by macrophytes were 161 simulated by adapting the first order rate processes used by Rousseau (2005), 162 which in turn were based on the work of Wynn and Liehr (2001). They were 163 considered to take place only during the growing season (GS) and 164 consequently the step function $\delta(t, G S)$ was introduced: $\delta=1$ if $t \in G S$ and $\delta=0$ if $165 \mathrm{t} \notin \mathrm{GS}$, where $\mathrm{t}$ is the time. Nutrient uptake by macrophyte was considered to 166 take place in the water column and the interaction between belowground 167 biomass and sediments was not included.

$$
\mathrm{FP}_{\mathrm{NH} 4}=\mathrm{S}_{\mathrm{NH} 4} \frac{\mathrm{S}_{\mathrm{NO} 3}}{\left(\mathrm{k}_{\mathrm{mN}}+\mathrm{S}_{\mathrm{NH} 4}\right)\left(\mathrm{k}_{\mathrm{mN}}+\mathrm{S}_{\mathrm{NO} 3}\right)}+\mathrm{S}_{\mathrm{NH} 4} \frac{\mathrm{k}_{\mathrm{mN}}}{\left(\mathrm{S}_{\mathrm{NH} 4}+\mathrm{S}_{\mathrm{NO} 3}\right)\left(\mathrm{k}_{\mathrm{mN}}+\mathrm{S}_{\mathrm{NO} 3}\right)} \quad \text { Eq. } 5
$$


Volatilization of $\mathrm{NH}_{3}$ was not included in the model since this process has little significance if the $\mathrm{pH}$ is below 9.3, which is the case of FWSCWs. Also in

171 SSFCWs, where $\mathrm{pH}$ varies between 7.5 and 8.0, this process is considered to 172 be insignificant (Saeed and Sun, 2012).

173 Following Gargallo et al. (2016), diffusion processes were modelled by 174 modifying Fick's first law with the parameter Kdifused, which takes into account 175 porosity and tortuosity for modelling diffusion between water and sediments.

176 In order to take into account the influence of phosphorus, phytoplankton and 177 total suspended solids (XTSS), these variables were modelled according to the 178 model developed by Gargallo et al. (2016). Matrix notation of the model for 179 simulating nitrogen forms, organic matter as well as phytoplankton, phosphorus 180 and total suspended solids is showed in Table 2, kinetic rates are presented in 181 Table 3 and stoichiometric coefficients in Table 4. Processes 1 to 14 are newly 182 developed in this study, whereas processes 15-24 are adapted from Gargallo et 183 al. (2016). Apart from processes included in Table 2, resuspension by wind was 184 modelled as Gargallo et al. (2016) in order to simulate resuspension of nitrogen 185 and organic matter content in sediments.

186 Processes 15 to 24 were modelled using the kinetic expressions by Gargallo et 187 al. (2016), whereas the growth of phytoplankton was modified by including the 188 Monod expression for the dissolved inorganic nitrogen, DIN, which is formed by 189 the sum of ammonium and nitrate.

190 Temperature influence was modelled using the modified Arrhenius Eq. 6:

$$
\mathrm{K}_{\mathrm{T}}=\mathrm{K}_{20} \theta^{\mathrm{T}-20}
$$

Eq. 6

191

192 where $\mathrm{K}_{\mathrm{T}}\left(\mathrm{d}^{-1}\right)$ is the value of the kinetic parameter at a certain temperature $\mathrm{T}$, $193 \mathrm{~K}_{20}\left(\mathrm{~d}^{-1}\right)$ is the value of the kinetic parameter at $20^{\circ} \mathrm{C}, \theta$ stands for the coefficient 194 of correction for temperature and $\mathrm{T}\left({ }^{\circ} \mathrm{C}\right)$ is operating temperature. 


\begin{tabular}{|c|c|c|c|c|c|c|c|c|c|c|c|c|c|c|}
\hline $\begin{array}{l}\text { Component } \rightarrow \\
\text { Process } \downarrow\end{array}$ & TIP & Pint & $\mathrm{S}_{\mathrm{NH} 4}$ & $\mathrm{~S}_{\mathrm{NO} 3}$ & $\mathrm{~S}_{\mathrm{s}}$ & $S_{i}$ & $X_{P}$ & $X_{H}$ & $X_{A}$ & $X_{s}$ & $x_{i}$ & $X_{m l}$ & $X_{m d}$ & $\mathrm{X}_{\mathrm{TSS}}$ \\
\hline 1. Hydrolysis & $\mathrm{U}_{1 \mathrm{TIP}}$ & & $\mathrm{U}_{1 \mathrm{NH} 4}$ & & 1- $f_{\text {hyd }, S i}$ & $f_{\text {hyd, Si }}$ & & & & -1 & & & & \\
\hline 2. Anoxic hydrolysis & $U_{2 T I P}$ & & $\mathrm{U}_{2 \mathrm{NH} 4}$ & & 1- fhyd,Si & fhyd,Si & & & & -1 & & & & \\
\hline 3. Aerobic growth of $\mathrm{X}_{H}$ & $\begin{aligned} &-\mathrm{i}_{\mathrm{Pbm}} \\
&+ \mathrm{i}_{\mathrm{PSS}} / \mathrm{Y}_{\mathrm{H}} \\
&\end{aligned}$ & & $i_{\mathrm{Nbm}}+\mathrm{i}_{\mathrm{NSS}} / \mathrm{Y}_{\mathrm{H}}$ & & $-1 / Y_{H}$ & & & 1 & & & & & & \\
\hline 4. Anoxic growth of $X_{H}$ & $\begin{aligned} & -\mathrm{i}_{\mathrm{Pbm}} \\
+ & \mathrm{iPSS}_{\mathrm{PS}} / \mathrm{YH}_{\mathrm{H}}\end{aligned}$ & & $i_{\text {inbm }}+i_{N S s} / Y_{H}$ & $-\left(1-Y_{H}\right) /\left(2.86 Y_{H}\right)$ & $-1 / Y_{H}$ & & & 1 & & & & & & \\
\hline 5. Lysis de $X_{H}$ & $U_{5 T I P}$ & & $\mathrm{U}_{5 \mathrm{NH} 4}$ & & $f_{b m, S s}$ & & & -1 & & $U_{5 X s}$ & $f_{b m, X i}$ & & & \\
\hline 6. Growth of $X_{A}$ & $-\mathrm{i}_{\mathrm{Pbm}}$ & & $-\mathrm{i}_{\mathrm{Nbm}}-1 / \mathrm{Y}_{\mathrm{A}}$ & $1 / Y_{A}$ & & & & & 1 & & & & & \\
\hline 7. Lysis de $X_{A}$ & $\mathrm{U}_{7 \mathrm{TIP}}$ & & $\mathrm{U}_{7 \mathrm{NH} 4}$ & & $\mathrm{fbm}_{\mathrm{bs}} \mathrm{Ss}$ & & & & -1 & $U_{7 X s}$ & $f_{b m, x i}$ & & & \\
\hline 8. $\mathrm{S}_{\mathrm{NH} 4}$ uptake by $\mathrm{X}_{\mathrm{ml}}$ & $-\mathrm{i}_{\mathrm{PXm}}$ & & $-\mathrm{i}_{\mathrm{NXm}}$ & & & & & & & & & 1 & & \\
\hline 9. $\mathrm{S}_{\mathrm{NO} 3}$ uptake by $\mathrm{X}_{\mathrm{ml}}$ & $-i_{P X m}$ & & & $-i_{N X m}$ & & & & & & & & 1 & & \\
\hline 10. $X_{\text {md }}$ degradation & $\mathrm{U}_{10 \mathrm{TIP}}$ & & $\mathrm{U}_{10 \mathrm{NH} 4}$ & & & & & & & 1- $f_{\text {plant }}$ & $f_{\text {plant }}$ & & -1 & \\
\hline 11. Diffusion of $\mathrm{S}_{\mathrm{NH} 4}$ & & & 1 & & & & & & & & & & & \\
\hline 12. Diffusion of $\mathrm{S}_{\mathrm{NO} 3}$ & & & & 1 & & & & & & & & & & \\
\hline 13. Sedimentation of $X_{s}$ & & & & & & & & & & -1 & & & & \\
\hline 14. Sedimentation of $X_{i}$ & & & & & & & & & & & -1 & & & \\
\hline 15. Phosphorus uptake by $X_{P}$ & $-X_{P}$ & 1 & & & & & & & & & & & & \\
\hline 16. Growth of $X_{P}$ & & $-\mathrm{i}_{\mathrm{PXp}} / \mathrm{X}_{\mathrm{P}}$ & $-\mathrm{FP}_{\mathrm{NH} 4} \cdot \mathrm{i}_{\mathrm{NXp}}$ & $-\left(1-F P_{N H 4}\right) \cdot i_{N X p}$ & & & 1 & & & & & & & iTssxp \\
\hline 17. Decay of $X_{P}$ & $\mathrm{U}_{17 T I P}$ & & $\mathrm{U}_{17 \mathrm{NH} 4}$ & & $f_{X p S s} \cdot i_{c o D X p}$ & & -1 & & & $\mathrm{U}_{17 \mathrm{Xs}}$ & $f_{X p X i} \cdot i_{C} \operatorname{codxp}$ & & & -їssxp \\
\hline 18. Lysis of Pint & $\mathrm{X}_{\mathrm{P}}$ & -1 & & & & & & & & & & & & \\
\hline 19. Respiration of $X_{p}$ & U $_{19 T I P}$ & & $\mathrm{U}_{19 \mathrm{NH} 4}$ & & fXpss.icodXp & & -1 & & & $U_{19 X s}$ & $f_{X p X i} \cdot i_{C O D X p}$ & & & $\begin{array}{c}- \\
\text { iTsSXp } \\
\end{array}$ \\
\hline 20. Sedimentation of $X_{P}$ & & & & & & & -1 & & & & & & & $\begin{array}{c}- \\
\text { İTSSXp }\end{array}$ \\
\hline 21. Sedimentation of PIP & -1 & & & & & & & & & & & & & \\
\hline 22. Diffusion of DIP & 1 & & & & & & & & & & & & & \\
\hline 23. Sedimentation of $X_{S S T}$ & & & & & & & & & & & & & & -1 \\
\hline 24. Resuspension by avifauna & & & & & & & & & & ícoDsed & & & & 1 \\
\hline
\end{tabular}




\begin{tabular}{|c|c|}
\hline Process & Process rate \\
\hline 1. Hydrolysis & $\mathrm{r}_{1}=\mathrm{k}_{\mathrm{h}} \cdot \theta_{\mathrm{kh}}^{\mathrm{T}-20} \frac{\mathrm{X}_{\mathrm{S}} / \mathrm{X}_{\mathrm{H}}}{\mathrm{k}_{\mathrm{x}}+\mathrm{X}_{\mathrm{s}} / \mathrm{X}_{\mathrm{H}}} \frac{\mathrm{DO}}{\mathrm{K}_{\mathrm{hyd} \text { Do }}+\mathrm{DO}} \mathrm{X}_{\mathrm{H}}$ \\
\hline 2. Anoxic hydrolysis & $\mathrm{r}_{2}=\mathrm{k}_{\mathrm{h}} \cdot 0_{\mathrm{h}} \cdot \theta_{\mathrm{kh}}^{\mathrm{T}-20} \frac{\mathrm{X}_{\mathrm{S}} / \mathrm{X}_{\mathrm{H}}}{\mathrm{k}_{\mathrm{x}}+\mathrm{X}_{\mathrm{s}} / \mathrm{X}_{\mathrm{H}}} \frac{\mathrm{K}_{\mathrm{hyd} \text { DO }}}{\mathrm{K}_{\mathrm{hyd} \mathrm{DO}}+\mathrm{D0} 0} \frac{\mathrm{S}_{\mathrm{NO} 3}}{\mathrm{k}_{\mathrm{NOH}}+\mathrm{S}_{\mathrm{NO} 3}} \mathrm{X}_{\mathrm{H}}$ \\
\hline 3. Aerobic growth $X_{H}$ & $r_{3}=\mu_{H} \cdot \theta_{\mu \mathrm{H}}^{T-20} \frac{S_{s}}{K_{s}+S_{s}} \frac{D O}{K_{O H}+D 0} \frac{S_{N H 4}}{K_{N H H}+S_{N H}} \frac{\mathrm{TIP} \cdot f_{d}}{K_{P H}+T I P \cdot f_{d}} X_{H}$ \\
\hline 4. Anoxic growth $X_{H}$ & $r_{4}=\eta_{\mathrm{NO} 3} \cdot \mu_{\mathrm{H}} \cdot \theta_{\mu \mathrm{H}}^{\mathrm{T}-20} \frac{\mathrm{S}_{\mathrm{s}}}{\mathrm{K}_{\mathrm{s}}+\mathrm{S}_{\mathrm{s}}} \frac{\mathrm{K}_{\mathrm{OH}}}{\mathrm{K}_{\mathrm{OH}}+\mathrm{DO}} \frac{\mathrm{S}_{\mathrm{NO} 3}}{\mathrm{~K}_{\mathrm{NOH}}+\mathrm{S}_{\mathrm{NO} O 3}} \frac{\mathrm{S}_{\mathrm{NH} 4}}{\mathrm{~K}_{\mathrm{NHH}}+\mathrm{S}_{\mathrm{NH} 4}} \frac{\mathrm{TIP} \cdot \mathrm{f}_{\mathrm{d}}}{\mathrm{K}_{\mathrm{PH}}+\mathrm{TIP} \cdot \mathrm{f}_{\mathrm{d}}} \mathrm{X}_{\mathrm{H}}$ \\
\hline 5. Lysis of $X_{H}$ & $\mathrm{r}_{5}=\mathrm{b}_{\mathrm{H}} \cdot \theta_{\mathrm{bH}}^{\mathrm{T}-20} \cdot \mathrm{X}_{\mathrm{H}}$ \\
\hline 6. Growth of $X_{A}$ & $\mathrm{r}_{6}=\mu_{\mathrm{A}} \cdot \theta_{\mu \mathrm{A}}{ }^{\mathrm{T}-20} \frac{\mathrm{S}_{\mathrm{NH} 4}}{\mathrm{~K}_{\mathrm{NHA}}+\mathrm{S}_{\mathrm{NH} 4}} \frac{\mathrm{DO}}{\mathrm{K}_{\mathrm{OA}}+\mathrm{D} 0} \frac{\mathrm{TIP} \cdot \mathrm{f}_{\mathrm{d}}}{\mathrm{K}_{\mathrm{PA}}+\mathrm{TIP} \cdot \mathrm{f}_{\mathrm{d}}} \mathrm{X}_{\mathrm{A}}$ \\
\hline 7. Lysis of $X_{A}$ & $\mathrm{r}_{7}=\mathrm{b}_{\mathrm{A}} \cdot \theta_{\mathrm{bA}}^{\mathrm{T}-20} \cdot \mathrm{X}_{\mathrm{A}}$ \\
\hline 8. Diffusion of $\mathrm{S}_{\mathrm{NH} 4}$ & $\mathrm{r}_{8}=\mathrm{Do}_{\mathrm{NH} 4} \cdot \theta_{\mathrm{dNH} 4}{ }^{\mathrm{T}-20} \cdot\left(\mathrm{NH}_{\mathrm{sed}}-\mathrm{S}_{\mathrm{NH} 4}\right) \cdot \frac{\mathrm{A}}{0.1 \cdot \mathrm{V}}$ \\
\hline 9. Diffusion of $\mathrm{S}_{\mathrm{NO}}$ & $\mathrm{r}_{9}=\mathrm{Do}_{\mathrm{NO} 3} \cdot \theta_{\mathrm{d} \mathrm{NO} 3}{ }^{\mathrm{T}-20} \cdot\left(\mathrm{NO}_{\mathrm{sed}}-\mathrm{S}_{\mathrm{NO} 3}\right) \cdot \frac{\mathrm{A}}{0.1 \cdot \mathrm{V}}$ \\
\hline $\begin{array}{l}\text { 10. Sedimentation of } \\
\mathrm{X}_{\mathrm{S}}\end{array}$ & $\mathrm{r}_{10}=\frac{\mathrm{vs}}{\mathrm{H}} \cdot\left(1+\mathrm{VC} \cdot \mathrm{K}_{\mathrm{vegsed}}\right) \cdot \mathrm{X}_{\mathrm{S}}$ \\
\hline 11. Sedimentation of $X_{1}$ & $r_{11}=\frac{v s_{X}}{H} \cdot\left(1+V C \cdot K_{v e g s e d}\right) \cdot X_{i}$ \\
\hline 12. $\mathrm{S}_{\mathrm{NH} 4}$ uptake by $\mathrm{X}_{\mathrm{ml}}$ & $\mathrm{r}_{12}=\frac{1}{\mathrm{H}} \cdot \mathrm{K}_{\mathrm{pl}} \cdot \theta_{\text {up plant }}^{\mathrm{T}-20} \frac{\mathrm{S}_{\mathrm{NH} 4}}{\mathrm{~K}_{\mathrm{NHP}}+\mathrm{S}_{\mathrm{NH} 4}} \frac{\mathrm{TIP} \cdot \mathrm{f}_{\mathrm{d}}}{\mathrm{K}_{\mathrm{PP}}+\mathrm{TIP} \cdot \mathrm{f}_{\mathrm{d}}} \mathrm{X}_{\mathrm{ml}} \cdot \delta(\mathrm{t}, \mathrm{GS})$ \\
\hline 13. $\mathrm{S}_{\mathrm{NO} 3}$ uptake by $\mathrm{X}_{\mathrm{ml}}$ & $\mathrm{r}_{13}=\frac{1}{\mathrm{H}} \cdot \mathrm{K}_{\mathrm{pl}} \cdot \theta_{\mathrm{up} \mathrm{plant}}{ }^{\mathrm{T}-20} \frac{\mathrm{S}_{\mathrm{NO3}}}{\mathrm{K}_{\mathrm{NOP}}+\mathrm{S}_{\mathrm{NO} O 3}} \frac{\mathrm{K}_{\mathrm{NHP}}}{\mathrm{K}_{\mathrm{NHP}}+\mathrm{S}_{\mathrm{NH} 4}} \frac{\mathrm{TIP} \cdot \mathrm{f}_{\mathrm{d}}}{\mathrm{K}_{\mathrm{PP}}+\mathrm{TIP} \cdot \mathrm{f}_{\mathrm{d}}} \mathrm{X}_{\mathrm{ml}} \cdot \delta(\mathrm{t}, \mathrm{GS})$ \\
\hline 14. Plant degradation & $\mathrm{r}_{14}=\frac{1}{\mathrm{H}} \cdot \mathrm{K}_{\mathrm{deg}} \cdot \theta_{\mathrm{deg}}^{\mathrm{T}-20} \cdot \mathrm{X}_{\mathrm{md}}$ \\
\hline
\end{tabular}

$$
\begin{aligned}
& v_{1 T I P}=v_{2 T I P}=i_{P X s}-f_{\text {hyd }, S i} \cdot i_{P S i}-\left(1-f_{\text {hyd }, S i}\right) \cdot i_{P S s} \\
& v_{1 N H 4}=v_{2 N H 4}=i_{N X s}-f_{h y d, S i} \cdot i_{N S i}-\left(1-f_{h y d, S i}\right) \cdot i_{N S s} \\
& v_{5 T I P}=v_{7 T I P}=i_{\text {Pbm }}-f_{b m S s} \cdot i_{\text {PSs }}-i_{\text {PXs }} \cdot\left(1-f_{\text {bmSs }}-f_{\text {bmXi }}\right)-i_{\text {PXi }} \cdot f_{b m X i} \\
& v_{5 N H 4}=v_{7 N H 4}=i_{N b m}-f_{b m S s} \cdot i_{N S s}-i_{N X s} \cdot\left(1-f_{b m S s}-f_{b m X i}\right)-i_{N X i} \cdot f_{b m X i} \\
& v_{5 \mathrm{Xs}}=\mathrm{v}_{7 \mathrm{Xs}}=1-\mathrm{f}_{\mathrm{bmSs}}-\mathrm{f}_{\mathrm{bmXi}} \\
& \mathrm{v}_{10 \text { TIP }}=\mathrm{i}_{\text {PXm }}-\mathrm{f}_{\text {plant }} \cdot \mathrm{i}_{\text {PXi }}-\left(1-\mathrm{f}_{\text {plant }}\right) \cdot \mathrm{i}_{\text {PXs }} \\
& \mathrm{v}_{10 \mathrm{NH} 4}=\mathrm{i}_{\mathrm{NXm}}-\mathrm{f}_{\text {plant }} \cdot \mathrm{i}_{\mathrm{NXi}}-\left(1-\mathrm{f}_{\text {plant }}\right) \cdot \mathrm{i}_{\mathrm{NXs}} \\
& v_{17 T I P}=v_{19 T I P}=i_{P X p}-f_{X p S s} \cdot i_{\text {CODXp }} \cdot i_{P S s}-\left(i_{\operatorname{coDXp}}\left(1-f_{X p S s}-f_{X p X i}\right)\right) \cdot i_{P X s}-f_{X p X i} \cdot i_{\operatorname{coDXp}} \cdot i_{P X i} \\
& v_{17 N H 4}=v_{19 N H 4}=i_{N X p}-f_{X p S s} \cdot i_{\text {CODXp }} \cdot i_{N S s}-\left(i_{\operatorname{coDXp}}\left(1-f_{X p S s}-f_{X p X i}\right)\right) \cdot i_{N X s}-f_{X p X i} \cdot i_{\operatorname{CoDXp}} \cdot i_{N X i} \\
& v_{17 X s}=v_{19 X s}=i_{\operatorname{CODXp}} \cdot\left(1-f_{X p S s}-f_{\text {XpXi }}\right)
\end{aligned}
$$


204 Data collected in the set of FWSCWs in Tancat de la Pipa were used to calibrate and

205

206

207

208

209

210

211

212

213

214

215

216

217 218 validate the model stated. Calibration was carried out in the FWSCW named as FG1 by adjusting parameter values in order to obtain the best fit between simulated and observed data (April 2009-April 2012). Afterwards, the model was validated using the data from the FWSCW FG2.

The model developed was implemented in the software AQUASIM (Reichert, 1994), which uses the variable-order Gear integration technique to solve differential equations (Reichert, 1998). Processes reactions were introduced as dynamic processes, components as state variables and the rest of parameters as programme, constant, real list or formula variables. The mixed reactor compartment configuration was used and defined by the volume of the wetland, active variables, active processes, initial conditions and inputs. Hydraulic performance of the systems FG1 and FG2 was simulated such as in Gargallo et al. (2016) by applying a mass balance.

Table 5. Initial conditions for the component concentrations in FWSCWs FG1 and FG2.

\begin{tabular}{|c|c|c|c|}
\hline \multirow{2}{*}{ Component } & \multirow{2}{*}{ Units } & \multicolumn{2}{|c|}{ Initial conditions } \\
\hline & & FG1(calibration) & FG2 (validation) \\
\hline $\mathrm{S}_{\mathrm{NH} 4}$ & $\mathrm{mg} \mathrm{N} \mathrm{L}^{-1}$ & 0.134 & 0.005 \\
\hline $\mathrm{S}_{\mathrm{NO} 3}$ & $\mathrm{mg} \mathrm{N} \mathrm{L}^{-1}$ & 0.848 & 0.018 \\
\hline $\mathrm{S}_{\mathrm{s}}$ & $\mathrm{mg} \mathrm{COD} \mathrm{L}^{-1}$ & 4.82 & 4.96 \\
\hline$S_{i}$ & $\mathrm{mg} \mathrm{COD} \mathrm{L}^{-1}$ & 19.28 & 19.84 \\
\hline$X_{s}$ & $m g C^{2 O D ~ L^{-1}}$ & 3.87 & 4.4 \\
\hline$X_{i}$ & $\mathrm{mg} \mathrm{COD} \mathrm{L}^{-1}$ & 0.53 & 0.6 \\
\hline$X_{H}$ & $\mathrm{mg} \mathrm{COD} \mathrm{L}^{-1}$ & 0.001 & 0.001 \\
\hline$X_{A}$ & $\mathrm{mg} \mathrm{COD} \mathrm{L}^{-1}$ & 0.001 & 0.001 \\
\hline$X_{m l}$ & $\mathrm{~g} \mathrm{COD} \mathrm{m}^{-2}$ & 505.4 & 505.4 \\
\hline$X_{m d}$ & $\mathrm{~g} \mathrm{COD} \mathrm{m}^{-2}$ & 0.005 & 0.005 \\
\hline TIP & $m g P^{-1}$ & 0.421 & 0.093 \\
\hline$P_{\text {int }}$ & $\mathrm{mg} \mathrm{P} \mathrm{mg} \mathrm{Chl} a^{-1}$ & 0.52 & 0.52 \\
\hline$X_{P}$ & $\mathrm{mg} \mathrm{Chl} \mathrm{a} \mathrm{L^{-1 }}$ & 0.007 & 0.001 \\
\hline$X_{\text {SST }}$ & $\mathrm{mg} \mathrm{L}^{-1}$ & 16.5 & 10.1 \\
\hline
\end{tabular}

220 Initial conditions were set to the concentrations measured in the outflow of the 221 systems during the first sampling campaign (Table 5). Initial concentrations of both 222 autotrophic and heterotrophic microorganisms were established in $0.001 \mathrm{mg} \mathrm{COD} \mathrm{L}^{-1}$ 223 in order to recreate the start-up situation and to reduce the impact of imposed initial 224 conditions (Samsó and Garcia, 2013). Microorganisms concentration in inflow water 225 was assumed to be null.

226 Regarding to macrophyte biomass, living and dead standing macrophyte biomasses 227 were introduced as input data. $X_{m l}$ and $X_{m d}$ were calculated from both VC and 228 maximum aboveground biomass reported by Gargallo et al. (2016) and Hernández- 
Crespo et al. (2016), respectively, since regular measurements of plant biomass were not available. Provided that FG1 and FG2 presented heterogeneous biomass distribution along their surfaces, it was considered that mean biomass density when the systems were fully vegetated $(\mathrm{VC}=1)$ was half the maximum value reported in the abovementioned study (i.e. $0.95 \mathrm{~kg} \mathrm{dw}^{-2}$, where $\mathrm{dw}$ means dry weight). Total biomass $\left(X_{m l}+X_{m d}\right)$ along the studied period was calculated by multiplying this

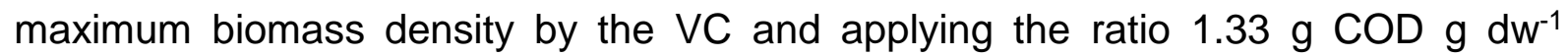
obtained from the same study (Hernández-Crespo et al., 2016). At the beginning of the studied period, $X_{m d}$ was considered to be negligible in both CWs since fresh biomass was planted (Martín et al., 2013). Macrophyte biomass in FG1 was harvested in October 2010 and vegetation did not grow up again so the entire aboveground biomass existing during the studied period was considered to be $X_{m l}$. On the other hand, FG2 was not harvested and vegetation started to globally decay from March 2010 until the end of the period (Oliver et al., 2016), thus a distribution between $X_{m l}$ and $X_{m d}$ was established based on field observations (Figure 1 ).

a)

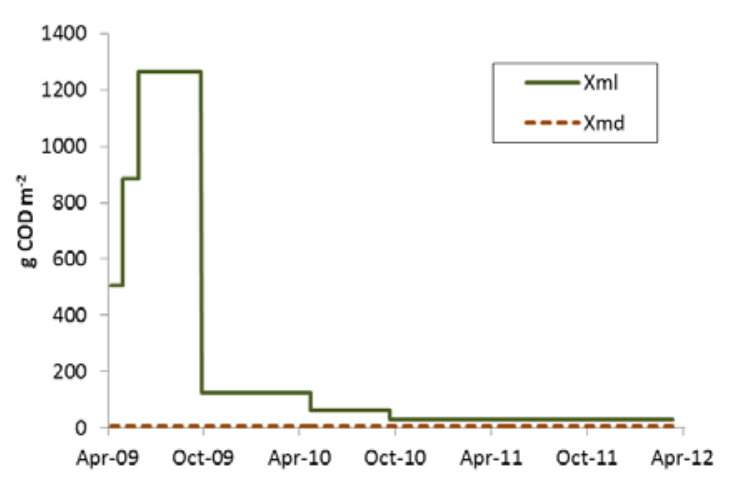

b)

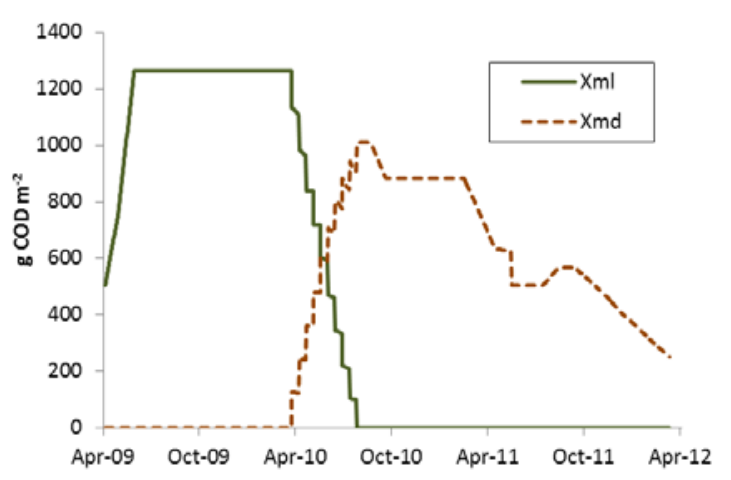

244

Figure 1. Estimated $X_{m l}$ and $X_{m d}\left(g_{C O D ~ m}^{-2}\right)$ in (a) FG1 and (b) FG2 FWSCWs.

Following the references compiled in Kadlec and Wallace (2009) for Typha spp., the growing season was considered to be from February to mid-September.

Nitrification and denitrification processes, which are respectively modelled by means of the growth of $\mathrm{X}_{\mathrm{A}}$ and the anoxic growth of $\mathrm{X}_{\mathrm{H}}$, are inversely affected by DO so they cannot occur at the same time within a completely mixed reactor compartment. In FWSCW these processes can be spatially separated since nitrification mainly occurs in areas where high DO concentrations are registered (e.g. near to water surface or near the rhizosphere) and denitrification takes places in water-sediment interface with lower DO concentrations (Babourina, 2012). Mainly due to phytoplankton photosynthesis and respiration, DO concentrations present notorious oscillations along one day in hypertrophic systems, which mostly depend on phytoplankton concentration, temperature, light intensity and nutrients availability. Since DO is an input variable in the proposed model, their values in the mixed reactor were introduced with a time step of 0.5 days. For each day, one of the values corresponds to diurnal conditions and the other one to nocturnal conditions, with linear 
interpolation connecting both points. Diurnal concentrations corresponded to 262 biweekly measured values, which were interpolated between each measurement. Continuous monitoring carried out seasonally was used for assigning minimum observed values as nocturnal DO concentrations: $5.03 \mathrm{mg} \mathrm{O}_{2} \mathrm{~L}^{-1}$ in spring, $1.27 \mathrm{mg}$ $\mathrm{O}_{2} \mathrm{~L}^{-1}$ in summer, $0.61 \mathrm{mg} \mathrm{O}_{2} \mathrm{~L}^{-1}$ in autumn and $3.51 \mathrm{mg} \mathrm{O}_{2} \mathrm{~L}^{-1}$ in winter (Figure 2).

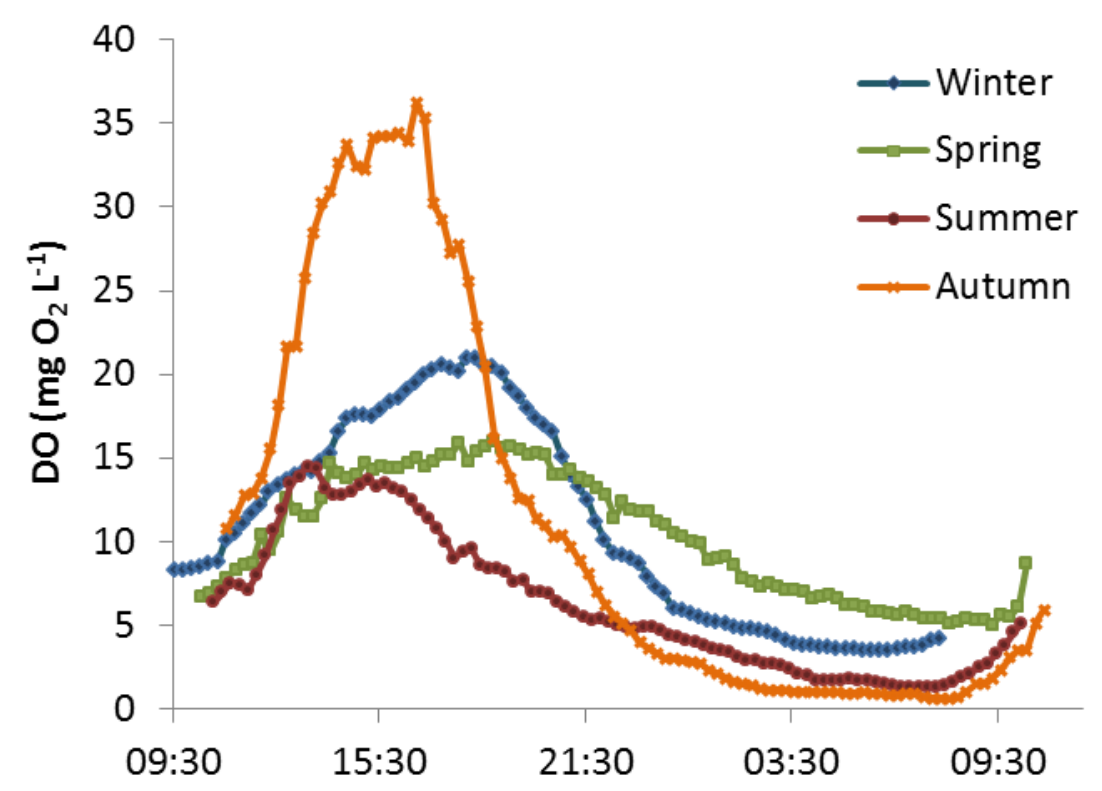

Figure 2. Seasonal daily evolution of DO concentrations in P1.

269 Values of the parameters used in Gargallo et al. (2016) were kept invariable during 270 the calibration procedure.

271 The root mean square error (RMSE, Eq. 7) was used to evaluate the adjustment of 272 the model by comparing simulated and observed outlet concentrations:

$$
\mathrm{RMSE}=\sqrt{\frac{\sum_{\mathrm{i}=1}^{\mathrm{n}}\left(\mathrm{Y}_{\mathrm{i}}^{\text {obs }}-\mathrm{Y}_{\mathrm{i}}^{\text {sim }}\right)^{2}}{\mathrm{n}}}
$$

274 where $\mathrm{Y}_{i}{ }^{\text {obs }}$ and $\mathrm{Y}_{i}{ }^{\mathrm{sim}}$ are observed and simulated concentrations, respectively, while $275 n$ is the total number of observations.

\subsection{Sensitivity analysis}

277 The parametric sensitivity of the model was studied in order to evaluate the influence

278 of each parameter in the model response. The relative sensitivity ( $\left.\mathrm{S}_{x}\right)$ (Hopkins, 279 1983) shows the influence of each parameter $k$ over each output variable $i$ (Eq. 8). 


$$
\mathrm{S}_{\mathrm{x}}=\frac{\Delta \mathrm{i} / \mathrm{i}}{\Delta \mathrm{k} / \mathrm{k}}
$$

Eq. 8

281

282

283

Mean values of $\mathrm{Sx}$ over $\mathrm{S}_{\mathrm{NH} 4}, \mathrm{~S}_{\mathrm{NO} 3}, \mathrm{TN}, \mathrm{CODT}$ and $\mathrm{COD}$ during the studied period were calculated in the system FG1 by introducing a variation of $\pm 10 \%(\Delta \mathrm{k}= \pm 0.1)$ over the calibration value of each parameter.

\section{Results and discussion}

\subsection{Calibration and validation results}

First results obtained by implementing the developed model did not satisfactorily reproduce field measurements. Simulated concentrations were more similar to those measured at the inlet than at the outlet of the studied FWSCWs. For example, in the case of nitrate, which is mainly removed by anoxic growth of $\mathrm{X}_{\mathrm{H}}$, mean concentrations of nitrate measured in $\mathrm{PO}$ and $\mathrm{P} 1$ were 2.13 and $0.98 \mathrm{mg} \mathrm{N} \mathrm{L}^{-1}$, respectively, whereas mean concentration simulated in $\mathrm{P} 1$ was $1.96 \mathrm{mg} \mathrm{N} \mathrm{L}^{-1}$. Low average concentrations of $X_{A}$ and $X_{H}$ were found in the systems: in FG1, $2 \cdot 10^{-5}$ and $2.85 \mathrm{mg} \mathrm{COD} \mathrm{L}^{-1}$, respectively. After carrying out some simulations and discarding important limitations due to the concentrations of substrates (e.g. $\mathrm{SNH}_{\mathrm{N}}, \mathrm{Ss}_{\mathrm{S}} \mathrm{S}_{\mathrm{NO} 3}$ )that could result in low values in the Monod expressions, it was stated that the mobility imposed to microorganisms (they were modelled as state variables) was generating those poor results. In order to solve this issue, the pattern used in CW2D for subsurface flow CWs (Langergraber and Šimůnek, 2005) was taken into account and microorganisms were considered to be immobile. They were not assumed to be floating in the water column but attached to available surfaces (e.g. surface layer of sediment, lateral banks in the FWSCW or submerged stems of vegetation). Provided that $X_{A}$ and $X_{H}$ were included as state variables in the model, an appropriate way to model their immobility feature in the mixed reactor in AQUASIM was to include a theoretical recirculation of microorganisms, considering that the large majority of them (99\%) were immobile in the system. Including this assumption was possible because this model does not aim to accurately study the biofilm in FWSCWs but to simulate main trends in nitrogen removal using a process-based model which includes, among other, the response of autotrophic and heterotrophic microorganisms. Taking into account the immobility feature of the microorganisms, the mean nitrate concentration simulated in $\mathrm{P} 1$ was $1.03 \mathrm{mg} \mathrm{N} \mathrm{L}^{-1}$, which is close to mean measured concentration. Mean simulated concentrations of $X_{A}$ and $X_{H}$ in FG1 increased to 0.76 and $107 \mathrm{mg} \mathrm{COD} \mathrm{L}^{-1}$, respectively, considering immobility feature.

Other models such as Llorens et al. (2011) consider the mobility of microorganisms in CWs and include bacteria input in the inflow. However, the recirculation approach 
presents the advantage that microorganisms remain in the system and the influence of growth and lysis processes can be studied.

317 On the other hand, an enhancement was needed in order to improve nitrate and organic matter simulation in FG1, where high values of RMSE were initially obtained (2.8 $\mathrm{mg} \mathrm{N} \mathrm{L}^{-1}$ for nitrate, $17.7 \mathrm{mg} \mathrm{L}^{-1}$ for CODT and $12.06 \mathrm{mg} \mathrm{L}^{-1}$ for CODs). It was stated that the lowest value for Monod expression during the studied period was obtained for $S_{s}$ (mean value of Monod expression for Ss was $0.28,0.90$ for $\mathrm{S}_{\mathrm{NO} 3}$, 0.66 for $\mathrm{S}_{\mathrm{NH} 4}$ and 0.86 for DIP). However, after some simulations, it was observed that nitrate and organic matter concentrations were better simulated when Monod expression for $\mathrm{S}_{\mathrm{s}}$ was fixed to 1 . This value for organic matter limitation could be assumed because anoxic growth of $\mathrm{X}_{H}$ takes place in the water sediment interface, where low DO concentrations occur and high organic matter accumulations were observed in this part of the system FG1. The results obtained by including this consideration better adjusted to observed data, especially for nitrate concentrations (RMSE for $\mathrm{S}_{\mathrm{NO}}$ was $1.09 \mathrm{mg} \mathrm{N} \mathrm{L}^{-1}$, for CODT was $15.9 \mathrm{mg} \mathrm{L}^{-1}$ and for CODs was 7.6 $\mathrm{mg} \mathrm{L}^{-1}$ ), and they suggest that organic matter needed for anoxic growth of $\mathrm{X}_{H}$ in system FG1 was supplied from these accumulations.

332 However, SNO3, CODt and CODs were properly simulated in FG2 using Monod 333 expression for Ss (RMSE were $0.57 \mathrm{mg} \mathrm{N} \mathrm{L}^{-1}, 12.9 \mathrm{mg} \mathrm{L}^{-1}$ and $8.1 \mathrm{mg} \mathrm{L}^{-1}$, 334 respectively) and the saturation coefficient for $\mathrm{Ss}(\mathrm{ks})$ was calibrated to $0.005 \mathrm{mg}$ $\mathrm{COD} \mathrm{L}^{-1}$. It means that limitation related to $\mathrm{Ss}$ in the anoxic growth of $\mathrm{X}_{\mathrm{H}}$ was weaker in FG2 because organic matter accumulations in this system were much smaller than in FG1 and therefore less Ss was supplied by this source.

Hereafter, the comparison between observed and simulated data for measured variables in FG1 and FG2 systems, including the abovementioned considerations, are presented (i.e. ammonium, nitrate, ON, TN, CODT and CODs).

Figure 3 and Figure 4 show that the model was successfully calibrated and validated since the main trends of nitrogen forms and organic matter concentrations observed in both FWSCWs were properly simulated.

Ammonium performance is well represented, showing better fitting when values are low. Furthermore, the model properly simulates the observed capacity of these FWSCWs for reducing ammonium peaks entering to the system. Despite the RMSE is high when comparing with mean inlet concentrations (Table 6), mean outlet observed and simulated concentrations are quite similar. Nitrate concentrations are successfully simulated in both systems.

ON and TN simulations, which were calculated using Eq. 1 and Eq. 2, presented different performances. ON was successfully simulated in calibration and validation procedures (RMSE $=0.07$ and $0.05 \mathrm{mg} \mathrm{N} \mathrm{L}^{-1}$, respectively), whereas modelled $\mathrm{TN}$ concentrations were significantly lower than observed ones. 
Regarding organic matter, the best results were obtained for CODs (RMSE $=7.6$ and $8.1 \mathrm{mg} \mathrm{L}^{-1}$, respectively). Conversely, the poorest fitting was obtained for CODT in FG1 and it could be due to the aforementioned large amount of particulate organic matter accumulated in the bottom of this system.
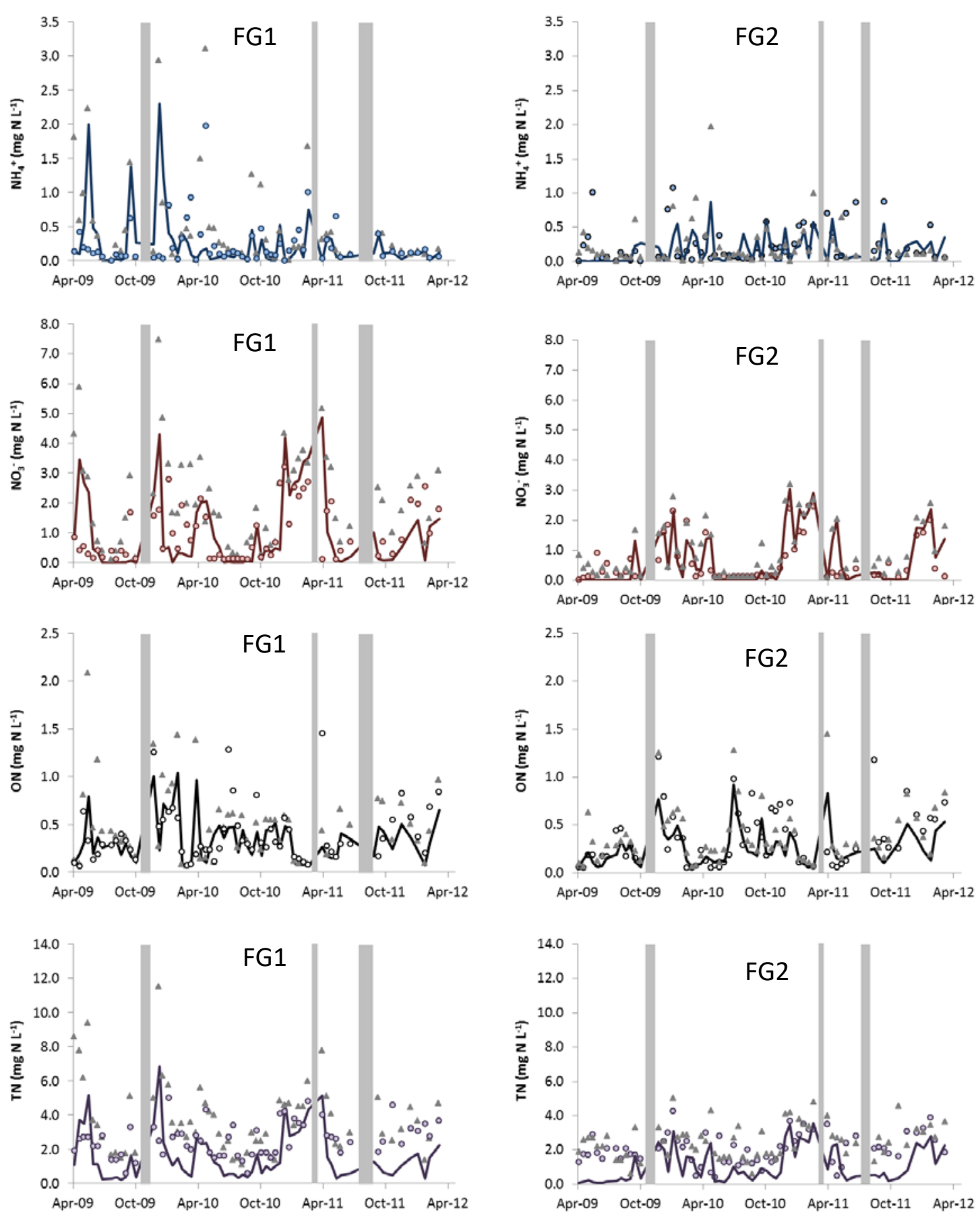

Figure 3. Temporal evolution of observed and simulated ammonium, nitrate, ON and TN concentrations in FG1 and FG2 FWSCWs. Triangles represent inlet concentrations, circles observed outlet concentrations and line simulated concentrations. Grey bars indicate dried periods in the CWs. 

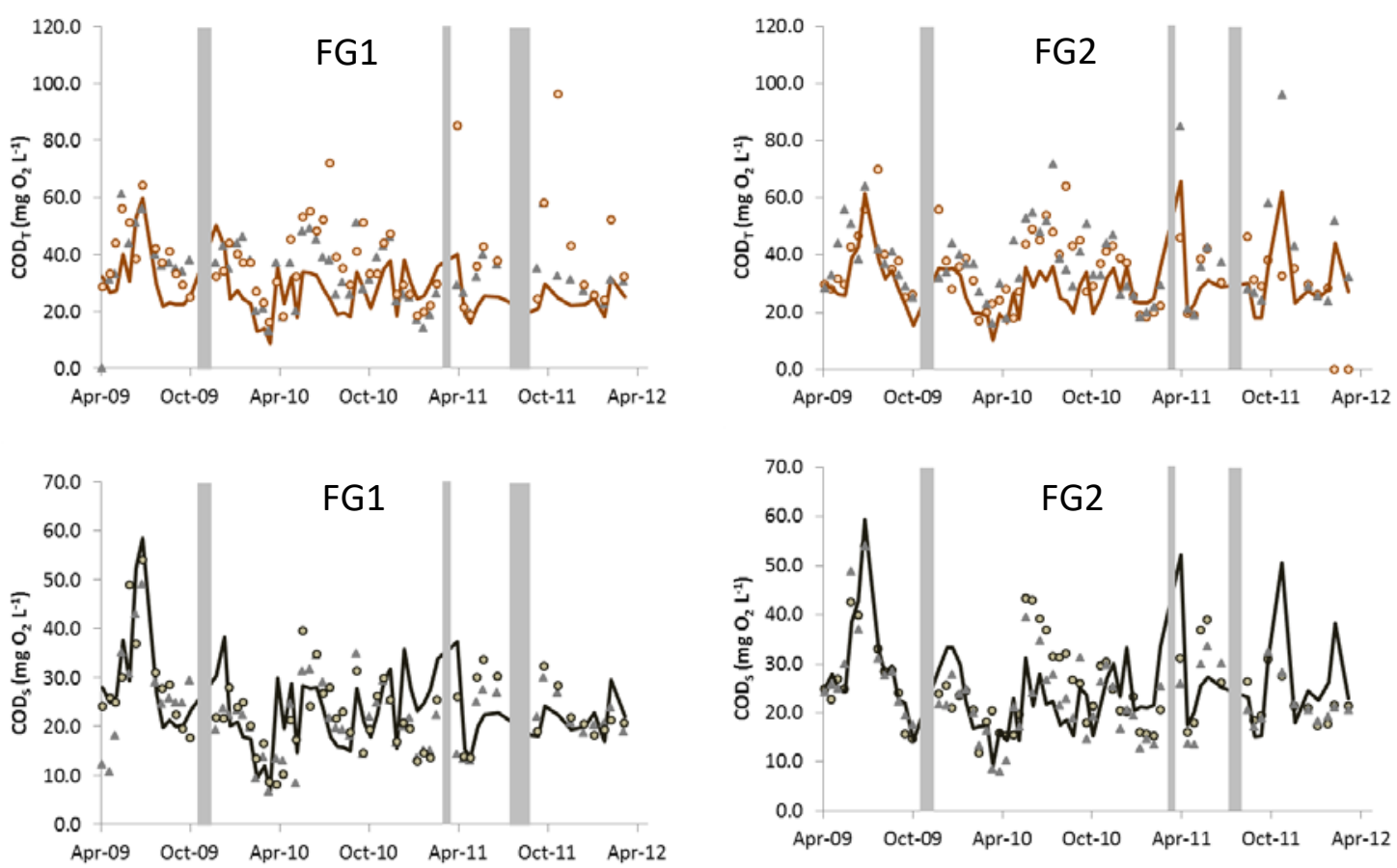

Figure 4. Temporal evolution of observed and simulated CODт and CODs concentrations in FG1 and FG2 FWSCWs. Triangles represent inlet concentrations, circles observed outlet concentrations and line simulated concentrations. Grey bars indicate dried periods in the CWs.

Table 6. Mean observed and simulated concentrations and RMSE obtained in calibration and validation procedures.

\begin{tabular}{|c|c|c|c|c|c|c|}
\hline & $\begin{array}{c}\text { Ammonium } \\
\left(\mathrm{mg} \mathrm{N} \mathrm{L}^{-1}\right)\end{array}$ & $\begin{array}{c}\text { Nitrate } \\
\left(\mathrm{mg} \mathrm{N} \mathrm{L}^{-1}\right)\end{array}$ & $\begin{array}{c}\text { ON } \\
\left(m g N L^{-1}\right)\end{array}$ & $\begin{array}{c}\mathrm{TN} \\
\left(\mathrm{mg} \mathrm{N} \mathrm{L}^{-1}\right)\end{array}$ & 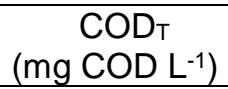 & $\begin{array}{c}\text { CODs } \\
\left(\mathrm{mg} \mathrm{COD} \mathrm{L}^{-1}\right)\end{array}$ \\
\hline \multicolumn{7}{|l|}{ FG1 (calibration) } \\
\hline $\begin{array}{l}\text { Mean inlet observed } \\
\text { concentration }\end{array}$ & 0.490 & 2.13 & 0.49 & 3.8 & 33.2 & 22.2 \\
\hline $\begin{array}{l}\text { Mean outlet } \\
\text { observed } \\
\text { concentration }\end{array}$ & 0.233 & 0.98 & 0.09 & 2.6 & 38.0 & 23.4 \\
\hline $\begin{array}{l}\text { Mean outlet } \\
\text { simulated } \\
\text { concentration }\end{array}$ & 0.286 & 1.03 & 0.03 & 1.7 & 32.1 & 23.8 \\
\hline RMSE & 0.556 & 1.09 & 0.07 & 1.6 & 15.9 & 7.6 \\
\hline \multicolumn{7}{|l|}{ FG2 (validation) } \\
\hline $\begin{array}{l}\text { Mean inlet observed } \\
\text { concentration }\end{array}$ & 0.230 & 0.97 & 0.09 & 2.5 & 37.8 & 23.4 \\
\hline $\begin{array}{l}\text { Mean outlet } \\
\text { observed } \\
\text { concentration }\end{array}$ & 0.240 & 0.62 & 0.07 & 2.1 & 35.1 & 25.1 \\
\hline $\begin{array}{l}\text { Mean outlet } \\
\text { simulated } \\
\text { concentration }\end{array}$ & 0.194 & 0.71 & 0.04 & 1.2 & 28.1 & 24.3 \\
\hline RMSE & 0.330 & 0.57 & 0.05 & 1.3 & 12.9 & 8.1 \\
\hline
\end{tabular}

371 The parameter values obtained in the calibration procedure are shown in Table 7 and 372 Table 8. The maximum growth velocity of heterotrophic microorganisms obtained by 
373 Mcbride and Tanner (2000) for modelling nitrogen removal in SSFCWs with water 374 level fluctuations was used, which is slightly lower than the value of $6 \mathrm{~d}^{-1}$ commonly 375 used in SSFCWs models (Langergraber et al., 2009; Langergraber and Šimůnek, 376 2005; Mburu et al., 2012; Samsó and Garcia, 2013).

377 Regarding $\mu_{\mathrm{A}}$, the calibrated value was very similar to the growth velocity of second 378 stage nitrifier microorganisms set by Reichert et al. (2001) (1.1 d $\left.\mathrm{d}^{-1}\right)$, presenting an 379 intermediate value between the $1 \mathrm{~d}^{-1}$ commonly used in CWM1, CW2D or BIO-pore 380 and the value of $1.5 \mathrm{~d}^{-1}$ set by Pálfy and Langergraber (2014).

Table 7. Stoichiometric parameters.

\begin{tabular}{|c|c|c|c|}
\hline Parameter & Description & Value & Source \\
\hline \multicolumn{4}{|c|}{ Phytoplankton } \\
\hline $\mathrm{K}_{\mathrm{mN}}$ & Saturation coefficient for $\mathrm{S}_{\mathrm{NH} 4}\left(\mathrm{mg} \mathrm{N} \mathrm{L}^{-1}\right)$ & 0.025 & $(1)$ \\
\hline \multicolumn{4}{|l|}{ Hydrolysis } \\
\hline $\mathrm{kh}_{\mathrm{h}}$ & Hydrolysis rate constant $\left(\mathrm{d}^{-1}\right)$ & 3 & (2) \\
\hline $\mathrm{O}_{\mathrm{h}}$ & Anoxic hydrolysis reduction factor & 0.6 & (2) \\
\hline Khyd DO & Saturation/inhibition coefficient for oxygen $\left(\mathrm{mg} \mathrm{O}_{2} \mathrm{~L}^{-1}\right)$ & 0.2 & (2) \\
\hline $\mathrm{k}_{\mathrm{x}}$ & Saturation/inhibition coefficient for hydrolysis (mg CODs mg CODbm ${ }^{-1}$ ) & 0.1 & (2) \\
\hline \multicolumn{4}{|c|}{ Heterotrophic bacteria } \\
\hline$\mu_{\mathrm{H}}$ & Maximum aerobic growth rate $\left(\mathrm{d}^{-1}\right)$ & 5 & (3) \\
\hline $\mathrm{b}_{\mathrm{H}}$ & Rate constant for lysis $\left(d^{-1}\right)$ & 0.4 & (2) \\
\hline$\eta_{\mathrm{NO}}$ & Correction factor for denitrification & 0.8 & (2) \\
\hline $\mathrm{K}_{\mathrm{NHH}}$ & Saturation coefficient for $\mathrm{S}_{\mathrm{NH} 4}\left(\mathrm{mg} \mathrm{N} \mathrm{L}^{-1}\right)$ & 0.05 & (2) \\
\hline $\mathrm{K}_{\mathrm{NOH}}$ & Saturation/inhibition coefficient for $\mathrm{S}_{\mathrm{NO} 3}\left(\mathrm{mg} \mathrm{N} \mathrm{L}^{-1}\right)$ & 0.05 & This study \\
\hline Ks & Saturation coefficient for Ss (mg COD L-1) & 0.005 & This study \\
\hline $\mathrm{KOH}$ & Saturation/inhibition coefficient for $\mathrm{DO}\left(\mathrm{mg} \mathrm{O}_{2} \mathrm{~L}^{-1}\right)$ & 0.5 & This study \\
\hline $\mathrm{K}_{\mathrm{PH}}$ & Saturation/inhibition coefficient for DIP (mg P $\left.\mathrm{L}^{-1}\right)$. & 0.001 & This study \\
\hline$\theta_{\mu \mathrm{H}}$ & Temperature coefficient for growth & 1.0718 & (2) \\
\hline$\theta_{\mathrm{bH}}$ & Temperature coefficient for lysis & 1.0718 & (2) \\
\hline$\theta_{\mathrm{Kh}}$ & Temperature coefficient for hydrolysis & 1.014 & (2) \\
\hline \multicolumn{4}{|c|}{ Autotrophic bacteria } \\
\hline$\mu_{\mathrm{A}}$ & Maximum growth rate $\left(d^{-1}\right)$ & 1.2 & This study \\
\hline$b_{A}$ & Rate constant for lysis $\left(\mathrm{d}^{-1}\right)$ & 0.15 & (2) \\
\hline $\mathrm{K}_{\mathrm{NHA}}$ & Saturation coefficient for $\mathrm{S}_{\mathrm{NH} 4}\left(\mathrm{mg} \mathrm{N} \mathrm{L}^{-1}\right)$ & 0.4 & This study \\
\hline KoA & Saturation coefficient for $\mathrm{DO}\left(\mathrm{mg} \mathrm{O}_{2} \mathrm{~L}^{-1}\right)$ & 1 & (4) \\
\hline$\theta_{\mu \mathrm{A}}$ & Temperature coefficient for growth & 1.1107 & (2) \\
\hline$\theta_{\mathrm{bA}}$ & Temperature coefficient for lysis & 1.1161 & (2) \\
\hline \multicolumn{4}{|c|}{ Interaction with sediment layer } \\
\hline $\mathrm{v}_{\mathrm{sX}}$ & Sedimentation rate of $X_{s}$ and $X_{i}\left(m^{-1}\right)$ & 0.03 & This study \\
\hline $\mathrm{DoNH}_{4}$ & Diffusion coefficient for $\mathrm{S}_{\mathrm{NH} 4}\left(\mathrm{~m}^{2} \mathrm{~d}^{-1}\right)$ & $1.71 \cdot 10^{-4}$ & (5) \\
\hline DonO3 & Diffusion coefficient for $\mathrm{S}_{\mathrm{NO} 3}\left(\mathrm{~m}^{2} \mathrm{~d}^{-1}\right)$ & $1.64 \cdot 10^{-4}$ & (5) \\
\hline$\theta_{\text {difu NH4 }}$ & Temperature coefficient for $\mathrm{S}_{\mathrm{NH} 4}$ diffusion & 1.0237 & (5) \\
\hline$\theta_{\text {difu NO3 }}$ & Temperature coefficient for $\mathrm{S}_{\mathrm{NO}}$ diffusion & 1.0239 & (5) \\
\hline \multicolumn{4}{|c|}{ r } \\
\hline $\mathrm{K}_{\mathrm{pl}}$ & Plant growth rate $\left(\mathrm{d}^{-1}\right)$ & 0.028 & $(6)$ \\
\hline$K_{\text {deg }}$ & Plant degradation rate $\left(\mathrm{d}^{-1}\right)$ & 0.0025 & This study \\
\hline $\mathrm{K}_{\mathrm{NHP}}$ & Saturation/inhibition coefficient for $\mathrm{S}_{\mathrm{NH} 4}\left(\mathrm{mg} \mathrm{N} \mathrm{L}^{-1}\right)$ & 0.1 & This study \\
\hline $\mathrm{K}_{\mathrm{NOP}}$ & Saturation coefficient for $\mathrm{S}_{\mathrm{NO} 3}\left(\mathrm{mg} \mathrm{N} \mathrm{L}^{-1}\right)$ & 0.1 & (7) \\
\hline $\mathrm{K}_{\mathrm{PP}}$ & Saturation coefficient for DIP ( $\left.\mathrm{mg} \mathrm{P} \mathrm{L}^{-1}\right)$. & 0.0005 & This study \\
\hline$\theta_{\text {up plant }}$ & Temperature coefficient for plant uptake & 1.09 & (8) \\
\hline$\theta_{\text {deg }}$ & Temperature coefficient for plant degradation & 1.0524 & (9) \\
\hline
\end{tabular}

(1): Ambrose et al. (1988); (2): Henze et al. (2000); (3): Mcbride and Tanner (2000); (4): Langergraber and Šimůnek (2005); (5): Reddy and DeLaune (2008); (6): Hernández-Crespo et al. (2016); (7): Kadlec and Knight (1996); (8): Asaeda and Karunaratne (2000); (9): Álvarez and Bécares (2006).

Many saturation/inhibition coefficients were lower than those commonly used for 386 treating domestic wastewater (Henze et al., 2000; Langergraber et al., 2009; Langergraber and Šimůnek, 2005; Samsó and Garcia, 2013) because hypertrophic 
water treated in FWSCWs FG1 and FG2 presented lower ammonium, nitrate and organic matter concentrations than domestic wastewater and lower saturation/inhibition coefficients were obtained for these variables. However, DO oscillations registered in the system provided higher inhibition/saturation coefficient for oxygen.

Nitrogen content in $X_{p}$ (inxp) was calculated by applying the Redfield mass ratio to the phytoplankton composition obtained in Gargallo et al. (2016), whereas phosphorus

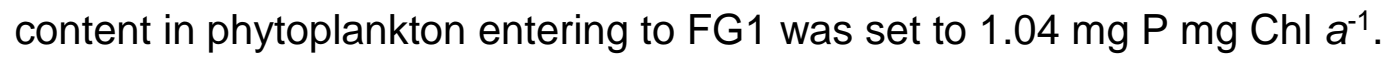

Regarding macrophyte composition, nitrogen content measured by HernándezCrespo et al. (2016) was used, which was lower than the value obtained by Romero et al. (1999) for Phragmites australis. This low content of nitrogen forced to fix lower nitrogen content, both in microorganisms and in organic matter forms than those usually used in order to accomplish mass balances. The plant growth rate set by Hernández-Crespo et al. (2016) was used and the calibrated plant degradation rate $\left(K_{d e g}=0.0025 \mathrm{~d}^{-1}\right)$ was very similar to the value of $0.0020 \mathrm{~d}^{-1}$ presented by Álvarez 403 and Bécares (2006).

404

405

406

407

Ammonium and nitrate concentrations in pore water in sediments were set to concentrations measured by Hernández-Crespo (2013) in sediments from Lake Albufera ( $\mathrm{NH}_{\text {sed }}=55 \mathrm{mg} \mathrm{N} \mathrm{L}^{-1}$ and $\mathrm{NO}_{\text {sed }}=0.4 \mathrm{mg} \mathrm{N} \mathrm{L}^{-1}$, respectively).

\begin{tabular}{|c|c|c|c|}
\hline Parameter & Description & Value & Source \\
\hline $\mathrm{Y}_{\mathrm{H}}$ & Yield coefficient for $\mathrm{X}_{H}\left(\mathrm{mg} \mathrm{COD}_{\mathrm{bm}} \mathrm{mg} \mathrm{COD} \mathrm{Ss}^{-1}\right)$ & 0.63 & $(2)$ \\
\hline $\mathrm{YA}_{\mathrm{A}}$ & Yield coefficient for $\mathrm{X}_{\mathrm{A}}\left(\mathrm{mg}\right.$ CODbm $\left.\mathrm{mg} \mathrm{N}^{-1}\right)$ & 0.24 & (2) \\
\hline fXpss & Fraction of Ss generated in $X_{p}$ decay and respiration (mg CODss $m g$ CODxp ${ }^{-1}$ ) & 0.1 & This study \\
\hline$f_{X p X i}$ & Fraction of $X_{i}$ generated in $X_{p}$ decay and respiration (mg CODxi $\mathrm{mg} \mathrm{COD} \mathrm{xp}^{-1}$ ) & 0.01 & This study \\
\hline fbmSs & Fraction of Ss generated in microorganisms lysis (mg CODss mg CODbm ${ }^{-1}$ ) & 0.1 & This study \\
\hline$f_{b m \times i}$ & Fraction of $X_{i}$ generated in microorganisms lysis (mg CODss mg COD $\mathrm{bm}^{-1}$ ) & 0.01 & This study \\
\hline$f_{\text {hyd, Si }}$ & Fraction of $X_{i}$ generated in hydrolysis $\left(\mathrm{mg} \mathrm{CODsi}_{\mathrm{si}} \mathrm{mg} \mathrm{CODxs}^{-1}\right)$ & 0 & (2) \\
\hline$f_{\text {plant }}$ & Fraction of $X_{i}$ generated in plant degradation (mg COD $x_{i} m g$ COD $\left.x_{m d^{-1}}\right)$ & 0.2 & (10) \\
\hline $\mathrm{i}_{\mathrm{NXp}}$ & $\mathrm{N}$ content of $\mathrm{X}_{\mathrm{p}}\left(\mathrm{mg} \mathrm{N} \mathrm{mg} \mathrm{Chl} \mathrm{a}^{-1}\right)$ & 7.52 & This study \\
\hline İCODXP & COD content of $X_{p}\left(\mathrm{mg} \mathrm{COD} \mathrm{mg} \mathrm{Chl} a^{-1}\right)$ & 114.01 & This study \\
\hline $\mathrm{i}_{\mathrm{Nbm}}$ & $\mathrm{N}$ content of microorganisms (mg N mg $\mathrm{CDO}_{\mathrm{bm}}^{-1}$ ) & 0.07 & $(2)$ \\
\hline $\mathrm{I}_{\mathrm{Pbm}}$ & $\mathrm{P}$ content of microorganisms (mg $\mathrm{P}$ mg $\mathrm{COD}_{\mathrm{bm}^{-1}}$ ) & 0.01 & This study \\
\hline $\mathrm{i}_{\mathrm{NXm}}$ & $\mathrm{N}$ content of microorganisms (mg N mg COD $\mathrm{bm}^{-1}$ ) & 0.07 & (6) \\
\hline $\mathrm{i}_{\text {NSs }}$ & $\mathrm{N}$ content of $\mathrm{Ss}_{\mathrm{s}}\left(\mathrm{mg} \mathrm{N} \mathrm{mg} \mathrm{CODss}{ }^{-1}\right)$ & 0.003 & This study \\
\hline înSi & $\mathrm{N}$ content of $\mathrm{Si}\left(\mathrm{mg} \mathrm{N} \mathrm{mg} \mathrm{CODsi}{ }^{-1}\right)$ & 0.001 & This study \\
\hline inXs & $\mathrm{N}$ content of $\mathrm{X}_{\mathrm{s}}\left(\mathrm{mg} \mathrm{N} \mathrm{mg} \mathrm{CODxs^{-1 } )}\right.$ & 0.004 & This study \\
\hline $\mathrm{i}_{\mathrm{NXi}}$ & $\mathrm{N}$ content of $\mathrm{X}_{\mathrm{i}}\left(\mathrm{mg} \mathrm{N} \mathrm{mg} \mathrm{CODxi}{ }^{-1}\right)$ & 0.003 & This study \\
\hline İPSs & $\mathrm{P}$ content of $\mathrm{Ss}\left(\mathrm{mg} \mathrm{P} \mathrm{mg} \mathrm{DQO}^{-1}\right)$ & 0.001 & This study \\
\hline ipsi & $\mathrm{P}$ content of $\mathrm{Si}\left(\mathrm{mg} \mathrm{P} \mathrm{mg} \mathrm{DQO}{ }^{-1}\right)$ & 0.000 & This study \\
\hline ipXs & $P$ content of $X_{s}\left(\mathrm{mg} \mathrm{P} \mathrm{mg} \mathrm{DQO}^{-1}\right)$ & 0.001 & This study \\
\hline İpxi & $\mathrm{P}$ content of $\mathrm{X}_{\mathrm{i}}\left(\mathrm{mg} \mathrm{P} \mathrm{mg} \mathrm{DQ} \mathrm{O}^{-1}\right)$ & 0.001 & This study \\
\hline İCoDsed & COD content of sediments ( $\mathrm{mg} \mathrm{COD} \mathrm{mg} \mathrm{TSS}{ }^{-1}$ ) & 0.07 & This study \\
\hline
\end{tabular}

The influence of alkalinity on the growth of $X_{A}$ was studied by applying the Monod 410 expression to the measurements carried out in points P0, P1 and P2 and using the 411 value of 0.5 mole $\mathrm{HCO}_{3}^{-} \mathrm{m}^{-3}$ for the saturation coefficient (Henze et al., 2000). The 412 Monod expression for alkalinity presented a mean value of 0.84 for the three studied 
points and the minimum value was 0.76 . These results suggested that alkalinity was 414 not exerting a substantial limitation in the growth of $\mathrm{X}_{\mathrm{A}}$.

415 The model properly represents the accumulated removed masses of ammonium and 416 nitrate in FWSCWs over time. Figure 5 and Figure 6 show the case of ammonium 417 and nitrate during the studied period. It can be seen the goodness-of-fit between 418 observed and simulated values in FG1, where the mean error is lower than 10\%. The 419 adjustment in FG2 is more adequate until January 2011 and from then on the model 420 overestimates ammonium removal and underestimates nitrate removal. The main 421 hypothesis is that it was produced by the decomposition of the stems cut by the 422 herbivorous bird Porphyrio porphyrio (Gargallo et al., 2016; Hernández-Crespo et al., 423 2016), which released ammonium in the water column and this contribution was not 424 modelled.

425

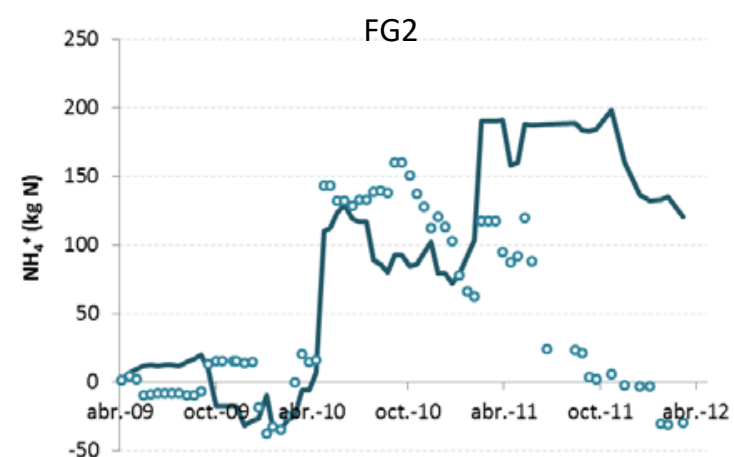

Figure 5. Accumulated mass of removed ammonium in FG1 and FG2. Points represent observed data and line simulated data.
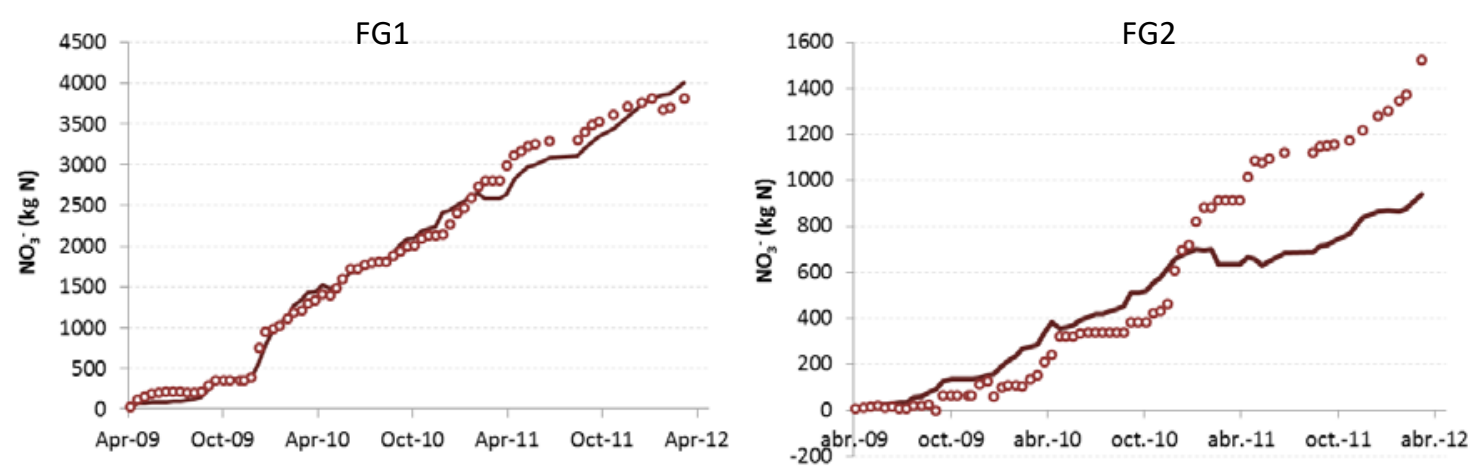

Figure 6. Accumulated mass of removed nitrate in FG1 and FG2. Points represent observed data and line simulated data. 
434 Pathways for ammonium and nitrate removal were studied in order to highlight the main removal mechanisms in FWSCWs. The influence of each process was calculated in reference to the sum of all the masses entering with influent and internally recycled by the simulated processes in the model.

In both FG1 and FG2 FWSCWs, ammonium was mainly removed by the growth of $\mathrm{X}_{\mathrm{A}}$ (Figure 7). In FG2 the contribution of this process was smaller in favour of the processes of heterotrophic microorganisms and plants. According to Oliver et al. (2016), the higher the VC, the higher the ammonium uptake by macrophytes, accounting $9 \%$ of the ammonium entering to FG1 and $19 \%$ to FG2.

In the balance of ammonium, the mass consumed by the aerobic and anoxic processes of growth as well as the mass recycled in the lysis of $\mathrm{X}_{\mathrm{H}}$ were counted as a single value. It represents $12 \%$ and $17 \%$ of the ammonium in FG1 and FG2, respectively, which is in accordance with the observations by Saeed and Sun (2012). The growth of $X_{P}$ consumes less than $2 \%$ of the ammonium in the system.

448

a)

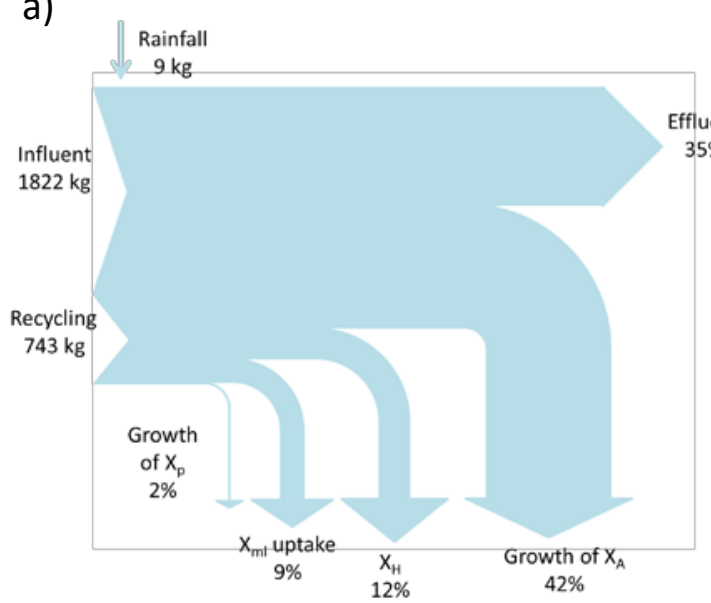
was confirmed. $5 \%$ of recycled ammonium. b)

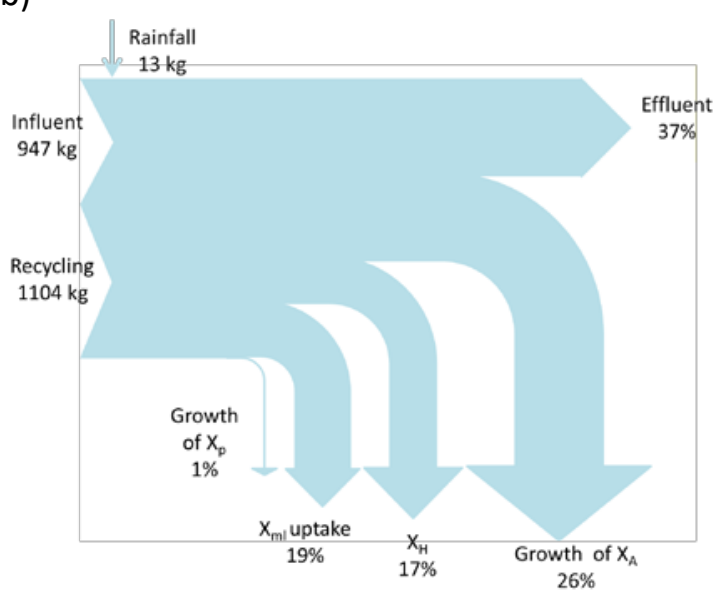

Figure 7. Budget of ammonium removal mechanisms in (a) FG1 and (b) FG2.

The amount of ammonium recycled by internal processes is higher in FG2 and the most contributing processes are diffusion, aerobic hydrolysis, decay and respiration of $X_{P}$ (Figure 8). The ammonium recycled by macrophyte degradation is negligible in FG1 because vegetation was harvested after the first year of operation, before the senescence of the vegetation; however, it plays an important role in FG2 and adds $8 \%$ of the recycled ammonium. Therefore, the importance of vegetation harvesting

In both systems, anoxic hydrolysis and lysis of microorganisms represent less than 
a)

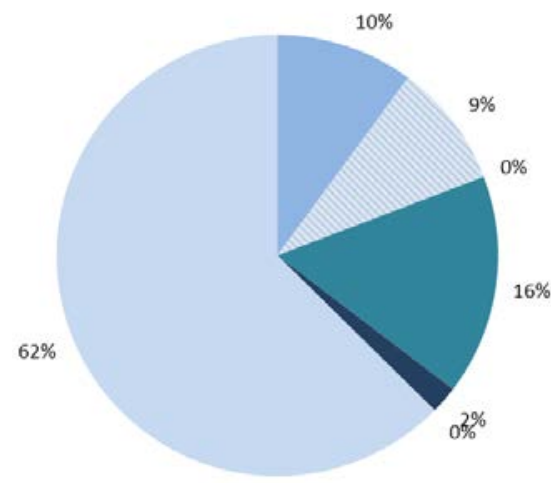

b)

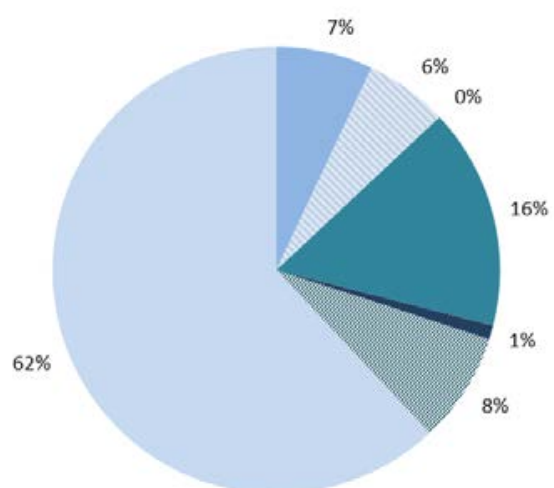

a)

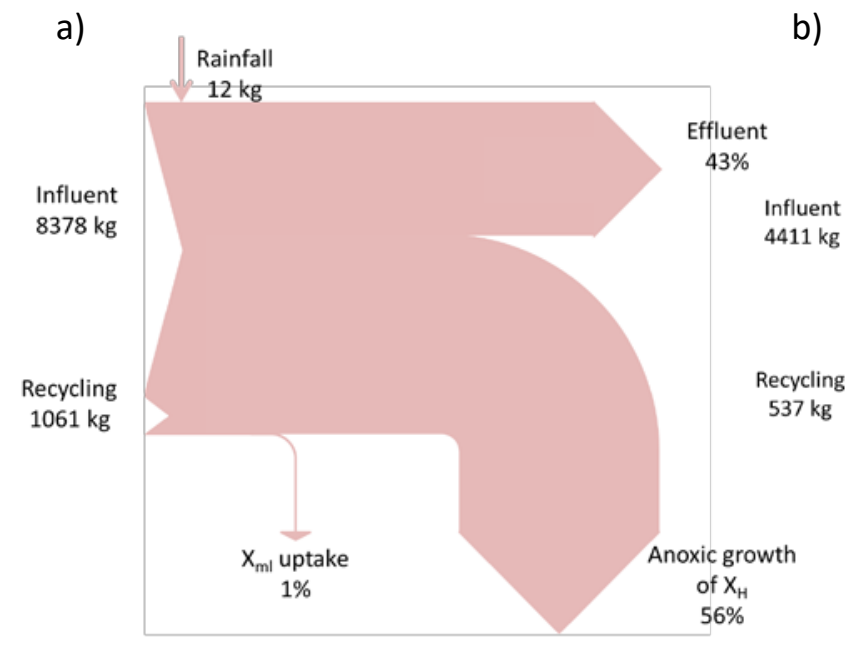

b)

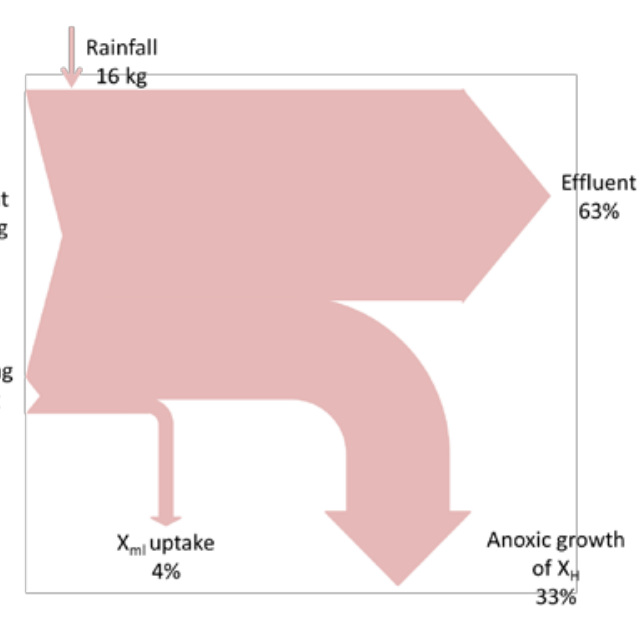

Figure 9. Budget of nitrate removal mechanisms in (a) FG1 and (b) FG2.

Regarding nitrate performance, it is mainly removed the anoxic growth of $X_{H}$ (Figure 9), which is consistent with the general assumption that denitrification is one of the most important mechanisms for nitrate removal in constructed wetlands (Garcia et al., 2010; Saeed and Sun, 2012; Sánchez-Carrillo et al., 2011). Nitrate removal by macrophyte uptake was lower than $5 \%$ in both systems. Internally recycled nitrate represents $11 \%$ of the amount entering to both systems and it is fully produced by the growth of $\mathrm{X}_{\mathrm{A}}$.

The results obtained in the sensitivity analysis (Table 9) showed that nitrate is the

\subsection{Sensitivity analysis results} most sensitive component in the model developed, followed by ammonium. Organic matter forms (CODT and CODs, calculated by means of Eq. 3 and Eq. 4) are less sensitive to changes in the parameter values. The most influential parameters for the five output variables studied are those related to growth and lysis kinetics of $X_{A}$ and 
$\mathrm{X}_{\mathrm{H}}$. Regarding temperature influence, ammonium is sensitive to temperature coefficient for the growth of $X_{A}$ and nitrate to temperature coefficient for the growth of both $X_{A}$ and $X_{H}$, whereas TN is influenced by the temperature coefficient for the growth of $\mathrm{X}_{\mathrm{H}}$. On the other hand, saturation coefficient for $\mathrm{S}_{\mathrm{NH} 4}$ and DO for the growth of $X_{A}$ are influential parameters in both ammonium and nitrate. Furthermore, TN is also sensitive to nitrogen content of $X_{P}$. CODT and CODs are sensitive to growth and lysis rates of $\mathrm{XH}_{\mathrm{H}}$, its yield coefficient and the correction factor for denitrification.

Table 9. Relative sensitivity $\left(S_{x}\right)$ ranking for simulated concentrations in the effluent.

\begin{tabular}{|c|c|c|c|c|c|}
\hline Sx & $\mathrm{S}_{\mathrm{NH} 4}$ & $\mathrm{~S}_{\mathrm{NO} 3}$ & $\mathrm{TN}$ & $\mathrm{COD}_{\mathrm{T}}$ & CODs \\
\hline$>1$ & $\mu_{\mathrm{A}}$ & $\mu_{\mathrm{H},} \eta_{\mathrm{NO}}, \mathrm{b}_{\mathrm{H}}$ & & & \\
\hline $\begin{array}{r}0.5-1 \\
0.1-0.5 \\
\end{array}$ & $\begin{array}{l}\mathrm{K}_{\mathrm{NHA}}, \mathrm{b}_{\mathrm{A}}, \theta_{\mu \mathrm{A}} \\
\mathrm{K}_{\mathrm{OA}}, \mathrm{b}_{\mathrm{H}}, \mathrm{Y}_{\mathrm{H}}\end{array}$ & $\begin{array}{l}\mu_{\mathrm{A}}, \mathrm{K}_{\mathrm{NHA}}, \mathrm{b}_{\mathrm{A}}, \mathrm{Y}_{\mathrm{H}} \\
\theta_{\mu \mathrm{A}}, \mathrm{K}_{\mathrm{h}}, \theta_{\mu \mathrm{H}}, \mathrm{K}_{\mathrm{OA}}\end{array}$ & $\begin{array}{l}\mu_{\mathrm{H}}, \eta_{\mathrm{NO}}, \\
\mathrm{b}_{\mathrm{H}}, \mathrm{i}_{\mathrm{NXp}}, \mathrm{Y}_{\mathrm{H}}, \theta_{\mu \mathrm{H}}\end{array}$ & $\mu_{\mathrm{H}}, \mathrm{b}_{\mathrm{H}}, \mathrm{Y}_{\mathrm{H}}, \eta_{\mathrm{NO}}$, & $\mu_{\mathrm{H}}, \mathrm{b}_{\mathrm{H}}, \mathrm{Y}_{\mathrm{H}}, \eta_{\mathrm{NO} O}$ \\
\hline
\end{tabular}

485

486

487

488

489

490

491

492

493

494

495

496

497

498

499

500

501

502

503

504

505

506

507

\section{Conclusions}

A process-based model following the structure of ASMs was developed for nitrogen forms simulation in FWSCWs treating eutrophic water. Using the software AQUASIM, it was properly calibrated and validated in two full scale systems operated for three years in real conditions.

The development of this model implies a considerable progress on the insight in nitrogen removal in FWSCWs and conclusions obtained in this study provide useful knowledge for maximizing nitrogen removal efficiency in FWSCWs.

The model includes the mechanisms related to heterotrophic and autotrophic microorganisms, phytoplankton and macrophytes. Immobility feature of the microorganisms was needed to be considered for properly reproducing observed concentrations in the effluent, so microorganisms were supposed to be attached in available surfaces. Aerobic and anoxic conditions were reproduced through diurnal and nocturnal oxygen oscillations, which are typical in hypertrophic water bodies. The effect of macrophyte uptake on nitrogen removal was simulated by means of the vegetation cover. 
508

509

510

511

512

513

514

515

516

517

518

519

520

521

522

523

524

525

526

527

528

529

530

531

532

533

534

535

536

537

538

539

540

Additionally, the quantification of the influence of each mechanism in ammonium removal showed that the main process for ammonium removal was the growth of autotrophic microorganisms, whereas anoxic growth of heterotrophic microorganisms was the most important process for nitrate removal. Plant uptake removed a substantial amount of dissolved inorganic nitrogen, especially in the system where vegetation cover was higher. Even so, an important quantity of ammonium was recycled in this system by plant degradation so appropriate harvesting could increase ammonium removal.

Finally, future research would be necessary in order to improve organic matter modelling. Furthermore, more knowledge is needed for clarifying microorganisms distribution along the available surface in the system, which would allow to answer questions such as where processes take place into FWSCWs and how harvesting or losing macrophyte biomass affect to microorganisms community.

\section{Acknowledgements}

We would like to acknowledge the support of Confederación Hidrográfica del Júcar (CHJ, MMARM) and the staff members in Tancat de la Pipa. We also acknowledge the anonymous reviewers and the editor for their valuable comments to improve this paper.

\section{References}

Álvarez, J.A., Bécares, E., 2006. Seasonal decomposition of Typha latifolia in a freewater surface constructed wetland. Ecol. Eng. 28, 99-105. doi:10.1016/j.ecoleng.2006.05.001

Ambrose, R.B., Wool, T.A., Connolly, J.P., Schanz, R.W., 1988. WASP4, A Hydrodynamic and Water Quality Model - Model Theory, User's Manual, and Programmer's Guide.

APHA, 1991. Standard Methods for the Examination of Water and Wastewater. Stand. Methods 541.

Arheimer, B., Pers, B.C., 2016. Lessons learned? Effects of nutrient reductions from constructing wetlands in 1996-2006 across Sweden. Ecol. Eng. 1-11. doi:10.1016/j.ecoleng.2016.01.088

Asaeda, T., Karunaratne, S., 2000. Dynamic modeling of the growth of Phragmites australis: model description. Aquat. Bot. 67, 301-318. doi:10.1016/S03043770(00)00095-4 
Galanopoulos, C., Lyberatos, G., 2016. Dynamic Modelling and design of free water surface constructed wetland systems 18.

Garcia, J., Rousseau, D.P.L., Morató, J., Lesage, E., Matamoros, V., Bayona, J.M., 2010. Contaminant removal processes in subsurface-flow constructed wetlands: a review. Crit. Rev. Environ. Sci. Technol. 40, 561-661. doi:10.1080/20016491089253

Gargallo, S., Martín, M., Oliver, N., Hernández-Crespo, C., 2016. Sedimentation and resuspension modelling in free water surface constructed wetlands. Ecol. Eng. doi:10.1016/j.ecoleng.2016.09.014

He, S.-B., Yan, L., Kong, H.-N., Liu, Z.-M., Wu, D.-Y., Hu, Z.-B., 2007. Treatment Efficiencies of Constructed Wetlands for Eutrophic Landscape River Water. Pedosphere 17, 522-528. doi:10.1016/S1002-0160(07)60062-9

Henze, M., Gujer, W., Mino, T., Loosdrecht, M. van, 2000. Activated Sludge Models ASM1, ASM2, ASM2d and ASM3. IWA Publishing.

Hernández-Crespo, C., 2013. Mid-term variation of vertical distribution of acid volatile sulphide and simultaneously extracted metals in sediment cores from Lake Albufera (Valencia, Spain). Arch. Environ. Contam. Toxicol. 65, 654-664. doi:10.1007/s00244-013-9941-1

Hernández-Crespo, C., Oliver, N., Bixquert, J., Gargallo, S., Martín, M., 2016. Comparison of three plants in a surface flow constructed wetland treating eutrophic water in a Mediterranean climate. Hydrobiologia 774, 183-192. doi:10.1007/s10750-015-2493-9

Hopkins, T., 1983. Quantitative analysis and simulation of Mediterranean coastal ecosystems: The Gulf of Naples, a case study. United Nations Educational, Scientific and Cultural Organization.

Kadlec, R.H., Knight, L., 1996. Treatment Wetlands, booksgooglecom. CRC Press, Boca Raton FL. doi:10.1201/9781420012514

Kadlec, R.H., Wallace, S.D., 2009. Treatment Wetlands, Second Edition.

Langergraber, G., 2008. Modeling of Processes in Subsurface Flow Constructed Wetlands: A Review. Vadose Zo. J. 7, 830. doi:10.2136/vzj2007.0054

Langergraber, G., Rousseau, D.P.L., García, J., Mena, J., 2009. CWM1: A general model to describe biokinetic processes in subsurface flow constructed wetlands. Water Sci. Technol. 59, 1687-1697. doi:10.2166/wst.2009.131

Langergraber, G., Šimůnek, J., 2005. Modeling Variably Saturated Water Flow and Multicomponent Reactive Transport in Constructed Wetlands. Vadose Zo. J. 4, 924. doi:10.2136/vzj2004.0166

Li, L., Li, Y., Biswas, D.K., Nian, Y., Jiang, G., 2008. Potential of constructed wetlands in treating the eutrophic water: Evidence from Taihu Lake of China. Bioresour. Technol. 99, 1656-1663. doi:10.1016/j.biortech.2007.04.001

Llorens, E., Saaltink, M.W., García, J., 2011. CWM1 implementation in 
RetrasoCodeBright: First results using horizontal subsurface flow constructed wetland data. Chem. Eng. J. 166, 224-232. doi:10.1016/j.cej.2010.10.065

Martín, M., Oliver, N., Hernández-Crespo, C., Gargallo, S., Regidor, M.C., 2013. The use of free water surface constructed wetland to treat the eutrophicated waters of lake L'Albufera de Valencia (Spain). Ecol. Eng. 50, 52-61.

Mburu, N., Sanchez-Ramos, D., Rousseau, D.P.L., van Bruggen, J.J.A., Thumbi, G., Stein, O.R., Hook, P.B., Lens, P.N.L., 2012. Simulation of carbon, nitrogen and sulphur conversion in batch-operated experimental wetland mesocosms. Ecol. Eng. 42, 304-315. doi:10.1016/j.ecoleng.2012.02.003

Mcbride, G.B., Tanner, C.C., 2000. Modelling biofilm nitrogen transformations in constructed wetland mesocosms with fluctuating water levels. Ecol. Eng. 14, 93106. doi:10.1016/S0925-8574(99)00022-1

Oliver, N., Martín, M., Gargallo, S., Hernández-Crespo, C., 2016. Influence of operational parameters on nutrient removal from eutrophic water in a constructed wetland. Hydrobiologia 1-16. doi:10.1007/s10750-016-3048-4

Pálfy, T.G., Langergraber, G., 2014. The verification of the constructed wetland model no. 1 implementation in HYDRUS using column experiment data. Ecol. Eng. 68, 105-115. doi:10.1016/j.ecoleng.2014.03.016

Reddy, K.R., DeLaune, R.D., 2008. Biogeochemistry of wetlands: science and applications. CRC press.

Reichert, P., 1998. AQUASIM 2.0 - User Manual. Computer Program for the Identication and Simulation of Aquatic Systems. Swiss Federal Institute for Environmental Science and Technology (EAWAG), Dubendorf.

Reichert, P., 1994. AQUASIM - A tool for simulation and data analysis of aquatic systems. Water Sci. Technol. 30, 21-30.

Reichert, P., Boarchardt, D., Henze, M., Rauch, W., Shanahan, P., Somlyódy, L., Vanrolleghem, P., 2001. River Water Quality Model No.1. IWA Publishing.

Romero, J.A.J.A., Brix, H., Comín, F.A., 1999. Interactive effects of $N$ and $P$ on growth, nutrient allocation and $\mathrm{NH} 4$ uptake kinetics by Phragmites australis. Aquat. Bot. 64, 369-380.

Rousseau, D.P.L., 2005. Performance of Constructed Treatment Wetlands: ModelBased Evaluation and Impact of Operation and Maintenance Werking Van Aangelegde Zuiveringsmoerassen: Modelgebaseerde Evaluatie En Impact Van. Environ. Technol. Ghent University, Ghent, Belgium,.

Saeed, T., Sun, G., 2012. A review on nitrogen and organics removal mechanisms in subsurface flow constructed wetlands: Dependency on environmental parameters, operating conditions and supporting media. J. Environ. Manage. $112,429-448$.

Samsó, R., Garcia, J., 2013. BIO_PORE, a mathematical model to simulate biofilm growth and water quality improvement in porous media: Application and calibration for constructed wetlands. Ecol. Eng. 54, 116-127. 
doi:10.1016/j.ecoleng.2013.01.021

Sánchez-Carrillo, S., Angeler, D.G., Álvarez-Cobelas, M., 2011. Freshwater wetland eutrophication, in: Eutrophication: Causes, Consequences and Control. p. 394.

Tang, X., Huang, S., Scholz, M., Li, J., 2009. Nutrient Removal in pilot-scale constructed wetlands treating eutrophic river water: Assessment of plants, intermittent artificial aeration and polyhedron hollow polypropylene balls. Water. Air. Soil Pollut. 197, 61-73. doi:10.1007/s11270-008-9791-z

Thomann, R. V, Fitzpatrick, J.J., 1982. Calibration and Verification of a Mathematical Model of the Eutrophication of the Potomac Estuary. DC Department of Environmental Sciences.

Wynn, T.M., Liehr, S.K., 2001. Development of a constructed subsurface-flow wetland simulation model. Ecol. Eng. 16, 519-536. doi:10.1016/S09258574(00)00115-4 